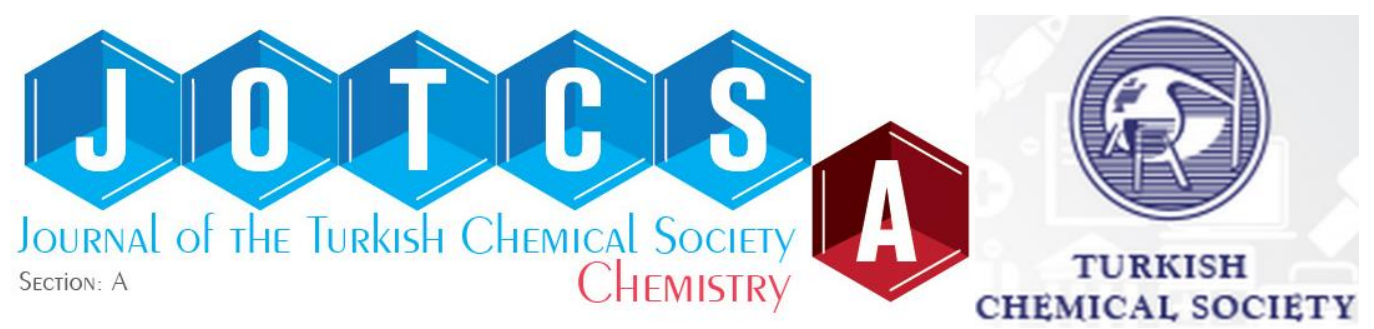

\title{
Preparation and Cytotoxicity Evaluation of Some Amino Acid Methyl Ester Schiff Bases
}

\author{
Nilay Akkuş Taş, Ayşegül Şenocak*, Ali Aydın \\ Gaziosmanpasa University, College of Art and Science, Department of Chemistry, 60240, \\ Tokat/TURKEY
}

\begin{abstract}
In this study, we prepared nine Schiff bases by condensation of amino acid methyl esters (isoleucine, phenylalanine, and methionine) with salicylaldehyde derivatives (2,4dihydroxybenzaldehyde, 2-hydroxy-3-methoxybenzaldehyde, and 5-bromo-2hydroxybenzaldehyde) and characterized by various spectroscopic methods (FT-IR, UV-Vis, and NMR techniques). FT-IR and UV-Vis spectra exhibited characteristic peaks for all imine compounds. NMR spectra pointed out the imine bond which is the indicator of the formation of Schiff bases. Besides, antiproliferative and cytotoxic features of the Schiff bases were examined by using MTT cell proliferation and LDH cytotoxicity assays, respectively. Amongst the synthesized Schiff bases, compound 3d exhibited a very strong antiproliferative effect against all cells except A549. The experimental studies revealed that the Schiff bases synthesized in this study, especially 3d, have an important potential to enter drug developmental studies.
\end{abstract}

Keywords: Amino acid Schiff bases, salicylaldehyde, antiproliferative activity, cytotoxicity, NMR spectra.

Submitted: January 03, 2018. Accepted: .March 27, 2018.

Cite this: Taş NA., Şenocak A., Aydın A. Preparation and Cytotoxicity Evaluation of Some Amino Acid Methyl Ester Schiff Bases. JOTCSA. 2018;5(2):585-606.

DOI: (to be assigned)

*Corresponding author. E-mail: aysegul.senocak@gop.edu.tr, Tel: +90 356252 1616/3051, Fax: +903562521585. 


\section{INTRODUCTION}

The nitrogen atom in an amine compound can attack to an electrophilic carbon atom of a carbonyl compound under certain conditions like acidic or basic media or with heating. This nucleophilic attack results in a compound known as Schiff base named after Hugo Schiff, who synthesized first this compound group in 1864 (1).

Schiff bases are regarded as very significant compounds because of their potential uses ranging from pharmacology and industry to biology and chemistry. According to the literature survey, Schiff bases have wide applications containing antibacterial (2-6), antifungal (7-11), anticancer (12-17), antimalarial (18-22), and antioxidant (23-28). Besides, they are convenient pioneers of a great number of compounds, such as a-branched amines $(29,30)$, tetramic acids (31), aand $\beta$-amino acids $(32,33)$, bicyclic lactams $(34,35)$, and oxaziridines $(36,37)$.

Amino acid-derived Schiff bases have attracted more attention because of incorporating amino acid component to the structure, taking important parts in chemical processes in living organisms. There are so many studies about the synthesis and the biological activities of amino acid Schiff bases and metal complexes. One of them focused on the effect of two amino acid Schiff bases on certain enzyme activities (38). The results showed that the Schiff bases acted as the activator or inhibitor on total, prostatic and non prostatic acid phosphatase enzymes depending upon their concentration. In another study, Zhang et al. synthesized chiral gossypol derivative Schiff bases (39). Some of the Schiff bases exhibited high anticancer activity, even higher than cisplatin anticancer drug. A series of benzaldehyde Schiff bases were prepared and their structure-microbicidal activity correlation was studied by Xia et al. (40). They expressed that the Schiff bases exhibited unique antibacterial activity and might be used for therapeutic purposes for bacterial infections. Another Schiff base series with aloin, a bioactive compound obtained from Aloe Vera, and amino acids was examined for anticancer and antioxidant properties (41). The results emphasized the enhanced antioxidant activity of aloin by the Schiff bases. The amino acid Schiff bases with a pyrazole derivative synthesized by Joksovic et al. were studied for anticancer activity (42). According to the results, the phenylalanine Schiff base was the most active compound against leukemic cell lines.

The purpose of this work was to synthesize nine Schiff bases (3a-i), from which the reduced form of 3a was known (43), from amino acid methyl esters and salicylaldehyde derivatives (Scheme 1). Structures of the obtained Schiff base compounds were elucidated by FT-IR and UV-Vis spectrometry, elemental analysis, ${ }^{1} \mathrm{H}$-NMR and ${ }^{13} \mathrm{C}-\mathrm{NMR}$ techniques. Besides, cytotoxic activities of aforesaid compounds were investigated. 
<smiles>[R]c1cc(C=O)c(O)c([R])c1[R]</smiles>

1a: $\mathrm{R}^{1}=\mathrm{Br}, \mathrm{R}^{2}=\mathrm{H}, \quad \mathrm{R}^{3}=\mathrm{H}$ 1b: $R^{1}=H, R^{2}=O H, R^{3}=H$ 1c: $R^{1}=H, R^{2}=H, \quad R^{3}=\mathrm{OCH}_{3}$

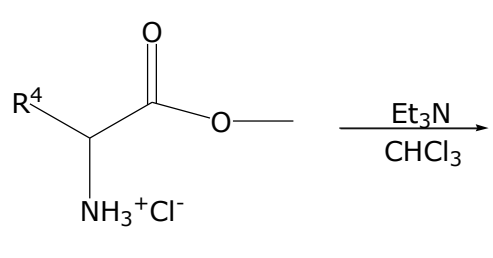

2a: $\mathrm{R}^{4}=\mathrm{CH}_{3} \mathrm{CH}_{2}\left(\mathrm{CH}_{3}\right) \mathrm{CH}$

2b: $\mathrm{R}^{4}=\mathrm{PhCH}_{2}$ 2c: $\mathrm{R}^{4}=\mathrm{CH}_{3} \mathrm{SCH}_{2} \mathrm{CH}_{2}$

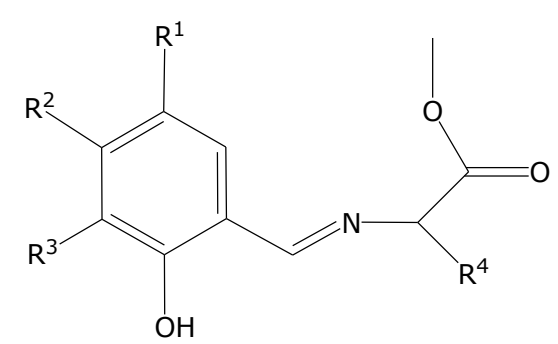

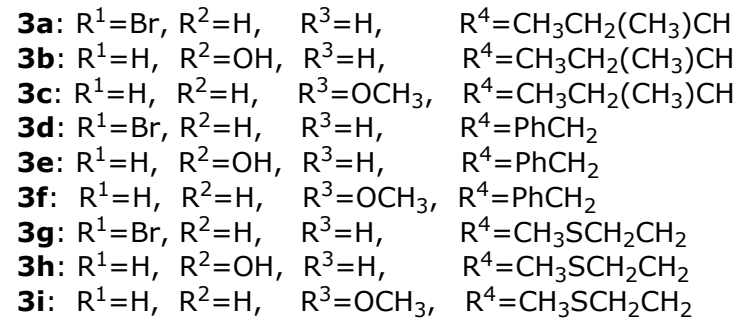

Scheme 1: The Schiff bases synthesized in this study.

\section{MATERIALS AND METHODS}

\section{Chemistry}

${ }^{1} \mathrm{H}-\mathrm{NMR}$ and ${ }^{13} \mathrm{C}$-NMR spectra of all imine compounds were measured using $\mathrm{AC}$ Bruker $400 \mathrm{MHz}$ NMR spectrometer in DMSO- $\mathrm{d}_{6}$ at ambient temperature. FT-IR spectra were recorded on a Jasco FT-IR 430 spectrometer in the range of $400-4000 \mathrm{~cm}^{-1}$ by using $\mathrm{KBr}$ pellets. UV-Vis absorption spectra were measured using a Perkin-Elmer Lambda 35 Spectrophotometer in a $10 \mathrm{~mm}$ quartz cell. The concentration of the Schiff base solutions prepared in methanol was about $10^{-4} \mathrm{M}$. Elemental analyses were recorded on a Elementar Vario Micro Cube elemental analyzer. Isoleucine, phenylalanine and methionine were used without purification and these amino acids were converted to corresponding methyl esters according to the literature (44). Solvents were used as received from commercial sources.

\section{Experimental Procedure For the Preparation of the Amino Acid Schiff Bases}

A round-bottomed flask containing amino acid methyl ester (2a-c) $(1 \mathrm{mmol}), \mathrm{N}(\mathrm{Et}))_{3}(0.7 \mathrm{mmol})$ and $\mathrm{CHCl}_{3}(20 \mathrm{~mL})$ was fitted with a reflux condenser. This mixture was refluxed until all amino acid was dissolved. When all content was dissolved, salicylaldehyde derivative (1a-c) (0.7 mmol) was added to the clear solution. The reaction mixture was refluxed a couple of days long. During this time the color of the solution has changed to yellow. The completion of the reaction was followed by TLC. After completion of the reaction, the reaction mixture was extracted with $\mathrm{CHCl}_{3}$ and $1 \mathrm{M} \mathrm{HCl}$. The extract was dried using $\mathrm{Na}_{2} \mathrm{SO}_{4}$ and evaporated under vacuum.

3a: Yield 65\%; FT-IR ( KBr, cm$\left.{ }^{-1}\right): 3458(\mathrm{O}-\mathrm{H}), 2963,2935,2876$ (aliphatic C-H), $1737(\mathrm{C}=\mathrm{O})$, 1630 (azomethine, $\mathrm{C}=\mathrm{N}$ ), 1256 (C-O phenolic); ${ }^{1} \mathrm{H}-\mathrm{NMR}$ (DMSO- $\left.\mathrm{d}_{6}, \delta, \mathrm{ppm}\right): 0.84(3 \mathrm{H}, \mathrm{d}$, $\left.{ }^{3} \mathrm{~J}_{H H}=1.5, \mathrm{CH}_{3}\right), 0.86\left(3 \mathrm{H}, \mathrm{t},{ }^{3} \mathrm{~J}_{H H}=7.3, \mathrm{CH}_{3}\right), 1.14\left(\mathrm{H}_{1}, \mathrm{~m}, \mathrm{CH}_{2}\right), 1.43\left(\mathrm{H}_{2}, \mathrm{~m}, \mathrm{CH}_{2}\right), 2.00(1 \mathrm{H}, \mathrm{m}$, $\mathrm{CH}), 3.67\left(3 \mathrm{H}, \mathrm{s}, \mathrm{OCH}_{3}\right), 4.02\left(1 \mathrm{H}, \mathrm{d}^{3}{ }^{3} \mathrm{~J}_{H H}=5.5, \mathrm{CH}\right), 6.86\left(1 \mathrm{H}, \mathrm{d},{ }^{3} \mathrm{~J}_{H H}=8.8, \mathrm{Ph}\right), 7.48(1 \mathrm{H}, \mathrm{dd}$, 
$\left.{ }^{3} J_{H H}=8.8,{ }^{4} J_{H H}=2.5, P h\right), 7.68\left(1 \mathrm{H}, \mathrm{d},{ }^{4} \mathrm{~J}_{H H}=2.5, \mathrm{Ph}\right), 8.53(1 \mathrm{H}, \mathrm{s}$, azomethine $), 13.39(1 \mathrm{H}, \mathrm{s}$, $\mathrm{OH}) .{ }^{13} \mathrm{C}-\mathrm{NMR}$ (DMSO-d6, $\left.\delta, \mathrm{ppm}\right): 11.16,15.56,24.54,37.98,51.94(\mathrm{OCH} 3), 74.84,109.38$ $(\mathrm{PhBr}), 119.01,120.19,133.63,135.17,159.68(\mathrm{PhOH}), 166.38$ (azomethine), $170.99(\mathrm{C}=0)$. Anal. calcd. for $\mathrm{C}_{14} \mathrm{H}_{18} \mathrm{BrNO}_{3}(328.2 \mathrm{~g} / \mathrm{mol}): \mathrm{C}, 51.23 ; \mathrm{H}, 5.53 ; \mathrm{N}, 4.27$. Found: $\mathrm{C}, 51.68 ; \mathrm{H}$, $6.27 ; \mathrm{N}, 4.96 \%$.

3b: Yield 94\%; FT-IR (KBr, cm$\left.{ }^{-1}\right)$ : $3371(\mathrm{O}-\mathrm{H}), 2960,2932,2876$ (aliphatic C-H), 1737 (C=O), 1638 (azomethine, $\mathrm{C}=\mathrm{N}$ ), 1227 ( $\mathrm{C}-\mathrm{O}$ phenolic); ${ }^{1} \mathrm{H}-\mathrm{NMR}$ (DMSO- $\left.\mathrm{d}_{6}, \delta, \mathrm{ppm}\right): 0.83(3 \mathrm{H}, \mathrm{d}$, $\left.{ }^{3} \mathrm{~J}_{H H}=6.7, \mathrm{CH}_{3}\right), 0.86\left(3 \mathrm{H}, \mathrm{t},{ }^{3} \mathrm{~J}_{H H}=7.7, \mathrm{CH}_{3}\right), 1.12\left(\mathrm{H}_{1}, \mathrm{~m}, \mathrm{CH}_{2}\right), 1.42\left(\mathrm{H}_{2}, \mathrm{~m}, \mathrm{CH}_{2}\right), 1.96(1 \mathrm{H}, \mathrm{m}$, $\mathrm{CH}), 3.65\left(3 \mathrm{H}, \mathrm{s}, \mathrm{OCH}_{3}\right), 3.91\left(1 \mathrm{H}, \mathrm{d},{ }^{3} \mathrm{~J}_{H H}=5.6, \mathrm{CH}\right), 6.20\left(1 \mathrm{H}, \mathrm{d},{ }^{4} \mathrm{~J}_{H H}=2.5, \mathrm{Ph}\right), 6.30(1 \mathrm{H}, \mathrm{dd}$, $\left.{ }^{3} \mathrm{~J}_{H H}=8.5,{ }^{4} \mathrm{~J}_{H H}=2.5, \mathrm{Ph}\right), 7.21\left(1 \mathrm{H}, \mathrm{d},{ }^{3} \mathrm{~J}_{H H}=8.5, \mathrm{Ph}\right), 8.37(1 \mathrm{H}, \mathrm{s}$, azomethine $), 13.64(1 \mathrm{H}, \mathrm{s}$, $\mathrm{OH}) .{ }^{13} \mathrm{C}-\mathrm{NMR}$ (DMSO-d $\left.6, \delta, \mathrm{ppm}\right): 11.16,15.63,24.54,37.91,51.83\left(\mathrm{OCH}_{3}\right), 74.43,102.40$, 107.22, 111.19, 133.57, 161.97 (azomethine), $163.44(\mathrm{PhOH}), 166.77(\mathrm{PhOH}), 171.48(\mathrm{C}=\mathrm{O})$. Anal. calcd. for $\mathrm{C}_{14} \mathrm{H}_{19} \mathrm{NO}_{4}(265.3 \mathrm{~g} / \mathrm{mol}): \mathrm{C}, 63.38 ; \mathrm{H}, 7.22 ; \mathrm{N}, 5.28$. Found: $\mathrm{C}, 63.51 ; \mathrm{H}, 7.26$; $\mathrm{N}, 4.87 \%$.

3c: Yield 73\%; FT-IR (KBr, cm$\left.{ }^{-1}\right): 3424(\mathrm{O}-\mathrm{H}), 2963,2935,2876$ (aliphatic C-H), $1739(\mathrm{C}=\mathrm{O})$, 1630 (azomethine, $\mathrm{C}=\mathrm{N}$ ), 1226 (C-O phenolic); ${ }^{1} \mathrm{H}-\mathrm{NMR}$ (DMSO- $\left.\mathrm{d}_{6}, \delta, \mathrm{ppm}\right): 0.84(3 \mathrm{H}, \mathrm{d}$, $\left.{ }^{3} \mathrm{~J}_{H H}=7.7, \mathrm{CH}_{3}\right), 0.87\left(3 \mathrm{H}, \mathrm{t},{ }^{3} \mathrm{~J}_{H H}=6.8, \mathrm{CH}_{3}\right), 1.15\left(\mathrm{H}_{1}, \mathrm{~m}, \mathrm{CH}_{2}\right), 1.43\left(\mathrm{H}_{2}, \mathrm{~m}, \mathrm{CH}_{2}\right), 2.03(1 \mathrm{H}, \mathrm{m}$, $\mathrm{CH}), 3.67\left(3 \mathrm{H}, \mathrm{s}, \mathrm{OCH}_{3}\right), 3.77\left(3 \mathrm{H}, \mathrm{s}, \mathrm{OCH}_{3}\right), 4.03\left(1 \mathrm{H}, \mathrm{d},{ }^{3} \mathrm{~J}_{\mathrm{HH}}=5.4, \mathrm{CH}\right), 6.82\left(1 \mathrm{H}, \mathrm{t},{ }^{3} \mathrm{~J}_{H H}=7.9\right.$, $\mathrm{Ph}), 7.03\left(1 \mathrm{H}, \mathrm{d},{ }^{3} \mathrm{~J}_{H H}=7.9, \mathrm{Ph}\right), 7.05\left(1 \mathrm{H}, \mathrm{d},{ }^{3} \mathrm{~J}_{H H}=7.9, \mathrm{Ph}\right), 8.53(1 \mathrm{H}, \mathrm{s}$, azomethine), 13.51 $(1 \mathrm{H}, \mathrm{s}, \mathrm{OH}) .{ }^{13} \mathrm{C}-\mathrm{NMR}$ (DMSO-d $\left.6, \delta, \mathrm{ppm}\right): 11.20,15.62,24.56,37.94,51.91\left(\mathrm{OCH}_{3}\right), 55.81$ $\left(\mathrm{OCH}_{3}\right), 74.65,115.25,118.11,118.28,123.34,147.95\left(\mathrm{Ph}-\mathrm{OCH}_{3}\right), 151.04(\mathrm{PhOH}), 167.93$ (azomethine), $171.19(\mathrm{C}=0)$. Anal. calcd. for $\mathrm{C}_{15} \mathrm{H}_{21} \mathrm{NO}_{4}(279.3 \mathrm{~g} / \mathrm{mol}): \mathrm{C}, 64.50 ; \mathrm{H}, 7.58 ; \mathrm{N}$, 5.01. Found: C, 64.86; H, 8.01; N, 5.52\%.

3d: Yield 78\%; FT-IR ( $\left.\mathrm{KBr}, \mathrm{cm}^{-1}\right)$ : $3382(\mathrm{O}-\mathrm{H})$, 3087,3061,3028 (aromatic C-H), 2950,2901 (aliphatic $\mathrm{C}-\mathrm{H}$ ), $1744(\mathrm{C}=\mathrm{O}), 1630$ (azomethine, $\mathrm{C}=\mathrm{N}$ ), 1276 (C-O phenolic); ${ }^{1} \mathrm{H}-\mathrm{NMR}$ (DMSO$\left.\mathrm{d}_{6}, \delta, \mathrm{ppm}\right): 3.09\left(1 \mathrm{H}, \mathrm{dd},{ }^{2} \mathrm{~J}_{H H}=13.6,{ }^{3} \mathrm{~J}_{H H}=8.2, \mathrm{CH}_{2}\right), 3.25\left(1 \mathrm{H}, \mathrm{dd},{ }^{2} \mathrm{~J}_{H H}=13.6,{ }^{4} \mathrm{~J}_{H H}=5.3, \mathrm{CH}_{2}\right)$, $3.65\left(3 \mathrm{H}, \mathrm{s}, \mathrm{OCH}_{3}\right), 4.43\left(1 \mathrm{H}, \mathrm{dd},{ }^{3} \mathrm{~J}_{H H}=8.2,{ }^{4} \mathrm{~J}_{H H}=5.3, \mathrm{CH}\right), 6.85\left(1 \mathrm{H}, \mathrm{d},{ }^{3} \mathrm{~J}_{H H}=8.8, \mathrm{Ph}\right), 7.18(3 \mathrm{H}$, $\mathrm{m}, \mathrm{Ph}), 7.26(2 \mathrm{H}, \mathrm{m}, \mathrm{Ph}), 7.45\left(1 \mathrm{H}, \mathrm{dd},{ }^{3} \mathrm{~J}_{H H}=8.8,{ }^{4} \mathrm{~J}_{H H}=2.5, \mathrm{Ph}\right), 7.57\left(1 \mathrm{H}, \mathrm{d},{ }^{4} \mathrm{~J}_{H H}=2.5, \mathrm{Ph}\right)$, $8.32\left(1 \mathrm{H}, \mathrm{s}\right.$, azomethine), $13.01(1 \mathrm{H}, \mathrm{s}, \mathrm{OH}) .{ }^{13} \mathrm{C}-\mathrm{NMR}$ (DMSO-d $\left.6, \delta, \mathrm{ppm}\right): 51.39,52.15\left(\mathrm{OCH}_{3}\right)$, 71.13, 118.98 (PhBr), 120.24, 126.31, 126.60, 128.27, 129.35, 133.39, 135.19, 136.68, 159.35 $(\mathrm{PhOH}), 166.17$ (azomethine), $170.82(\mathrm{C}=\mathrm{O})$. Anal. calcd. for $\mathrm{C}_{17} \mathrm{H}_{16} \mathrm{BrNO}_{3}(362.2 \mathrm{~g} / \mathrm{mol})$ : C, $56.37 ; \mathrm{H}, 4.45 ; \mathrm{N}, 3.87$. Found: $\mathrm{C}, 56.97 ; \mathrm{H}, 4.63 ; \mathrm{N}, 3.51 \%$.

3e: Yield 63\%; FT-IR $\left(\mathrm{KBr}, \mathrm{cm}^{-1}\right)$ : $3390(\mathrm{O}-\mathrm{H}), 3059,3028$ (aromatic C-H), 2950,2926 (aliphatic $\mathrm{C}-\mathrm{H}$ ), $1741\left(\mathrm{C}=\mathrm{O}\right.$ ), 1626 (azomethine, $\mathrm{C}=\mathrm{N}$ ), 1221 (C-O phenolic); ${ }^{1} \mathrm{H}-\mathrm{NMR}$ (DMSO-d $6, \delta, \mathrm{ppm}$ ): $3.04\left(1 \mathrm{H}, \mathrm{dd},{ }^{2} \mathrm{~J}_{H H}=13.6,{ }^{3} \mathrm{~J}_{H H}=8.2, \mathrm{CH}_{2}\right), 3.21\left(1 \mathrm{H}, \mathrm{dd},{ }^{3} \mathrm{~J}_{H H}=13.6,{ }^{4} \mathrm{~J}_{H H}=5.4, \mathrm{CH}_{2}\right), 3.64(3 \mathrm{H}, \mathrm{s}$, 
$\left.\mathrm{OCH}_{3}\right), 4.33\left(1 \mathrm{H}, \mathrm{dd},{ }^{3} \mathrm{~J}_{H H}=8.2,{ }^{4} \mathrm{~J}_{H H}=5.4, \mathrm{CH}\right), 6.19\left(1 \mathrm{H}, \mathrm{d},{ }^{4} \mathrm{~J}_{H H}=2.2, \mathrm{Ph}\right), 6.27\left(1 \mathrm{H}, \mathrm{dd},{ }^{3} \mathrm{~J}_{H H}=8.4\right.$, $\left.{ }^{4} \mathrm{~J}_{H H}=2.2, \mathrm{Ph}\right), 7.09\left(1 \mathrm{H}, \mathrm{d},{ }^{3} \mathrm{~J}_{H H}=8.4, \mathrm{Ph}\right), 7.18(3 \mathrm{H}, \mathrm{m}, \mathrm{Ph}), 7.25(2 \mathrm{H}, \mathrm{m}, \mathrm{Ph}), 8.15(1 \mathrm{H}, \mathrm{s}$, azomethine), $13.29(1 \mathrm{H}, \mathrm{s}, \mathrm{OH}) .{ }^{13} \mathrm{C}-\mathrm{NMR}$ (DMSO-d $\left., \delta, \mathrm{ppm}\right): 52.03,70.74\left(\mathrm{OCH}_{3}\right), 79.16$, $102.34,107.26,111.15,126.50,128.23,129.35,133.53,136.97,161.90$ (azomethine), 162.96 $(\mathrm{PhOH}), 166.88(\mathrm{PhOH}), 171.27(\mathrm{C}=\mathrm{O})$. Anal. calcd. for $\mathrm{C}_{17} \mathrm{H}_{17} \mathrm{NO}_{4}(299.3 \mathrm{~g} / \mathrm{mol}): \mathrm{C}, 68.21 ; \mathrm{H}$, 5.72; N, 4.68. Found: C, 68.16; H, 5.91; N, 4.44\%.

3f: Yield 88\%; FT-IR ( $\left.\mathrm{KBr}, \mathrm{cm}^{-1}\right)$ : $3412(\mathrm{O}-\mathrm{H}), 3061,3028,3003$ (aromatic C-H), 2950,2938 (aliphatic C-H), $1741(\mathrm{C}=\mathrm{O}), 1632$ (azomethine, $\mathrm{C}=\mathrm{N}$ ), 1224 (C-O phenolic); ${ }^{1} \mathrm{H}-\mathrm{NMR}$ (DMSO$\left.\mathrm{d}_{6}, \delta, \mathrm{ppm}\right): 3.08\left(1 \mathrm{H}, \mathrm{dd},{ }^{2} \mathrm{~J}_{H H}=13.5,{ }^{3} \mathrm{~J}_{H H}=8.3, \mathrm{CH}_{2}\right), 3.25\left(1 \mathrm{H}, \mathrm{dd},{ }^{2} \mathrm{~J}_{H H}=13.5,{ }^{4} \mathrm{~J}_{H H}=5.3, \mathrm{CH}_{2}\right)$, $3.66\left(3 \mathrm{H}, \mathrm{s}, \mathrm{OCH}_{3}\right), 3.76\left(3 \mathrm{H}, \mathrm{s}, \mathrm{OCH}_{3}\right), 4.44\left(1 \mathrm{H}, \mathrm{dd},{ }^{3} \mathrm{~J}_{H H}=8.3,{ }^{4} \mathrm{~J}_{H H}=5.3, \mathrm{CH}\right), 6.78(1 \mathrm{H}, \mathrm{t}$, $\left.{ }^{3} J_{H H}=7.9, \mathrm{Ph}\right), 6.90\left(1 \mathrm{H}, \mathrm{d},{ }^{3} \mathrm{~J}_{H H}=7.9, \mathrm{Ph}\right), 7.03\left(1 \mathrm{H}, \mathrm{d},{ }^{3} \mathrm{~J}_{H H}=7.9, \mathrm{Ph}\right), 7.19(3 \mathrm{H}, \mathrm{m}, \mathrm{Ph}), 7.26$ $(2 \mathrm{H}, \mathrm{m}, \mathrm{Ph}), 8.32\left(1 \mathrm{H}, \mathrm{s}\right.$, azomethine). ${ }^{13} \mathrm{C}-\mathrm{NMR}$ (DMSO-d $\left., \delta, \mathrm{ppm}\right): 51.29,52.11\left(\mathrm{OCH}_{3}\right), 55.73$ $\left(\mathrm{OCH}_{3}\right), 70.97,115.16,118.19,123.20,126.24,126.56,128.08,128.26,129.16,129.37$, $137.91,147.83\left(\mathrm{Ph}-\mathrm{OCH}_{3}\right), 150.58(\mathrm{PhOH}), 167.94$ (azomethine), $170.99(\mathrm{C}=0)$. Anal. calcd. for $\mathrm{C}_{18} \mathrm{H}_{19} \mathrm{NO}_{4}(313.4 \mathrm{~g} / \mathrm{mol}): \mathrm{C}, 68.99 ; \mathrm{H}, 6.11 ; \mathrm{N}, 4.47$. Found: $\mathrm{C}, 69.71 ; \mathrm{H}, 6.82 \mathrm{~N}, 4.64 \%$.

3g: Yield 86\%; FT-IR (KBr, cm$\left.{ }^{-1}\right): 3436(\mathrm{O}-\mathrm{H}), 2953,2916,2840$ (aliphatic C-H), $1741(\mathrm{C}=\mathrm{O})$, 1632 (azomethine, $\mathrm{C}=\mathrm{N}$ ), 1276 (C-O phenolic); ${ }^{1} \mathrm{H}-\mathrm{NMR}$ (DMSO- $\mathrm{d}_{6}, \delta, \mathrm{ppm}$ ): $2.03\left(3 \mathrm{H}, \mathrm{s}, \mathrm{SCH}_{3}\right.$ ), $2.08\left(\mathrm{H}_{1}, \mathrm{~m}, \mathrm{CH}_{2}\right), 2.18\left(\mathrm{H}_{2}, \mathrm{~m}, \mathrm{CH}_{2}\right), 2.42\left(\mathrm{H}_{1}, \mathrm{~m}, \mathrm{CH}_{2}\right), 2.49\left(\mathrm{H}_{2}, \mathrm{~m}, \mathrm{CH}_{2}\right), 3.68\left(3 \mathrm{H}, \mathrm{s}, \mathrm{OCH}_{3}\right)$, $4.30\left(1 \mathrm{H}, \mathrm{dd},{ }^{3} \mathrm{~J}_{H H}=7.9,{ }^{4} \mathrm{~J}_{H H}=5.0, \mathrm{CH}\right), 6.87\left(1 \mathrm{H}, \mathrm{d},{ }^{3} \mathrm{~J}_{H H}=8.8, \mathrm{Ph}\right), 7.48\left(1 \mathrm{H}, \mathrm{dd},{ }^{3} J_{H H}=8.8\right.$, $\left.{ }^{4} \mathrm{~J}_{H H}=2.5, \mathrm{Ph}\right), 7.71\left(1 \mathrm{H}, \mathrm{d},{ }^{4} \mathrm{~J}_{H H}=2.5, \mathrm{Ph}\right), 8.57\left(1 \mathrm{H}, \mathrm{s}\right.$, azomethine). ${ }^{13} \mathrm{C}-\mathrm{NMR}$ (DMSO-d $6, \delta$, ppm) : $14.46\left(\mathrm{SCH}_{3}\right), 29.20\left(\mathrm{SCH}_{2}\right), 32.15,52.25\left(\mathrm{OCH}_{3}\right), 68.52,109.55(\mathrm{PhBr}), 118.97,120.40$, 133.55, 135.23, $159.36(\mathrm{PhOH}), 166.55$ (azomethine), $171.05(\mathrm{C}=\mathrm{O})$. Anal. calcd. for $\mathrm{C}_{13} \mathrm{H}_{16} \mathrm{BrNO}_{3} \mathrm{~S}(346.2 \mathrm{~g} / \mathrm{mol}): \mathrm{C}, 45.10 ; \mathrm{H}, 4.66 ; \mathrm{N}, 4.05$. Found: $\mathrm{C}, 45.38 ; \mathrm{H}, 5.54 ; \mathrm{N}, 4.73 \%$.

3h: Yield 69\%; FT-IR (KBr, cm$\left.{ }^{-1}\right)$ : $3412(\mathrm{O}-\mathrm{H}), 2953,2916,2837$ (aliphatic C-H), $1740(\mathrm{C}=\mathrm{O})$, 1630 (azomethine, $\mathrm{C}=\mathrm{N}$ ), 1226 (C-O phenolic); ${ }^{1} \mathrm{H}-\mathrm{NMR}$ (DMSO-d6, $\delta, \mathrm{ppm}$ ): $2.02\left(3 \mathrm{H}, \mathrm{s}, \mathrm{SCH}_{3}\right.$ ), $2.06\left(2 \mathrm{H}, \mathrm{m}, \mathrm{CH}_{2}\right), 2.47\left(2 \mathrm{H}, \mathrm{m}, \mathrm{CH}_{2}\right), 3.66\left(3 \mathrm{H}, \mathrm{s}, \mathrm{OCH}_{3}\right), 4.19(1 \mathrm{H}, \mathrm{s}, \mathrm{CH}), 6.21(1 \mathrm{H}, \mathrm{s}, \mathrm{Ph})$, $6.32\left(1 \mathrm{H}, \mathrm{d},{ }^{3} \mathrm{~J}_{\mathrm{HH}}=8.0, \mathrm{Ph}\right), 7.24\left(1 \mathrm{H}, \mathrm{d},{ }^{3} \mathrm{~J}_{H H}=8.0, \mathrm{Ph}\right), 8.40(1 \mathrm{H}, \mathrm{s}$, azomethine $), 13.20(1 \mathrm{H}, \mathrm{s}$, $\mathrm{OH}) .{ }^{13} \mathrm{C}-\mathrm{NMR}$ (DMSO-d $\left.6, \delta, \mathrm{ppm}\right): 14.50\left(\mathrm{SCH}_{3}\right), 29.30\left(\mathrm{SCH}_{2}\right), 32.33,52.14\left(\mathrm{OCH}_{3}\right), 68.08$, 102.35, 107.37, 111.20, 133.66, 162.04 (azomethine), 162.96 (PhOH), 167.28 (PhOH), 171.49 $(\mathrm{C}=\mathrm{O})$. Anal. calcd. for $\mathrm{C}_{13} \mathrm{H}_{17} \mathrm{NO}_{4} \mathrm{~S}(283.3 \mathrm{~g} / \mathrm{mol}): \mathrm{C}, 55.11 ; \mathrm{H}, 6.05 ; \mathrm{N}, 4.94$. Found: $\mathrm{C}, 55.80$; $\mathrm{H}, 6.63 ; \mathrm{N}, 5.71 \%$.

3i: Yield 78\%; FT-IR ( $\left.\mathrm{KBr}, \mathrm{cm}^{-1}\right): 3435(\mathrm{O}-\mathrm{H}), 2950,2913,2837$ (aliphatic C-H), $1740(\mathrm{C}=\mathrm{O})$, 1630 (azomethine, $\mathrm{C}=\mathrm{N}$ ), 1227 (C-O phenolic); ${ }^{1} \mathrm{H}-\mathrm{NMR}$ (DMSO- $\left.\mathrm{d}_{6}, \delta, \mathrm{ppm}\right): 2.02\left(3 \mathrm{H}, \mathrm{s}, \mathrm{SCH}_{3}\right.$ ), $2.10\left(\mathrm{H}_{1}, \mathrm{~m}, \mathrm{CH}_{2}\right), 2.18\left(\mathrm{H}_{2}, \mathrm{~m}, \mathrm{CH}_{2}\right), 2.43\left(\mathrm{H}_{1}, \mathrm{~m}, \mathrm{CH}_{2}\right), 2.50\left(\mathrm{H}_{2}, \mathrm{~m}, \mathrm{CH}_{2}\right), 3.67\left(3 \mathrm{H}, \mathrm{s}, \mathrm{OCH}_{3}\right)$, $3.78\left(3 \mathrm{H}, \mathrm{s}, \mathrm{OCH}_{3}\right), 4.30\left(1 \mathrm{H}, \mathrm{dd},{ }^{3} \mathrm{~J}_{H H}=7.9,{ }^{4} \mathrm{~J}_{H H}=5.0, \mathrm{CH}\right), 6.83\left(1 \mathrm{H}, \mathrm{t},{ }^{3} \mathrm{~J}_{H H}=7.9, \mathrm{Ph}\right), 7.05(1 \mathrm{H}$, 
$\left.\mathrm{d},{ }^{3} \mathrm{~J}_{\mathrm{HH}}=7.9, \mathrm{Ph}\right), 7.06\left(1 \mathrm{H}, \mathrm{d},{ }^{3} \mathrm{~J}_{H H}=7.9, \mathrm{Ph}\right), 8.58(1 \mathrm{H}, \mathrm{s}$, azomethine $), 13.12(1 \mathrm{H}, \mathrm{s}, \mathrm{OH}) .{ }^{13} \mathrm{C}-$ NMR (DMSO-d $6, \delta, \mathrm{ppm}): 14.48\left(\mathrm{SCH}_{3}\right), 29.25\left(\mathrm{SCH}_{2}\right), 32.23,52.21\left(\mathrm{OCH}_{3}\right), 55.82\left(\mathrm{OCH}_{3}\right)$, 68.36, 115.33, 118.27, 118.41, 123.36, $147.89\left(\mathrm{Ph}-\mathrm{OCH}_{3}\right), 150.63$ (Ph-OH), 168.31 (azomethine), $171.19(\mathrm{C}=0)$. Anal. calcd. for $\mathrm{C}_{14} \mathrm{H}_{19} \mathrm{NO}_{4} \mathrm{~S}(297.4 \mathrm{~g} / \mathrm{mol}): \mathrm{C}, 56.55 ; \mathrm{H}, 6.44 ; \mathrm{N}$, 4.71. Found: C, 57.28; H, 6.89; N, 5.00\%.

\section{BIOLOGICAL ACTIVITY}

\section{MTT Cell Proliferation Assay}

HT29 (Human colorectal adenocarcinoma, ATCC ${ }^{\circledR}$ HTB-38 ${ }^{\mathrm{TM}}$ ), HeLa (Human cervix adenocarcinoma, ATCC $^{\circledR} \mathrm{CCL}^{2}{ }^{\mathrm{TM}}$ ), MCF7 (Human breast adenocarcinoma, ATCC $^{\circledR} \mathrm{HTB}^{\mathrm{TM}}{ }^{\mathrm{TM}}$ ), A549 (Human lung carcinoma, ATCC ${ }^{\circledR} \mathrm{CCL} 185^{\mathrm{TM}}$ ), C6 (Rat brain glioma, ATCC ${ }^{\circledR}$ CCL-107 ${ }^{\mathrm{TM}}$ ), and Hep3B (Human hepatocellular carcinoma, ATCC ${ }^{\circledR}$ HB8064 ${ }^{\mathrm{TM}}$ ) cancer cells and, FL (Human amnion cells, ATCC ${ }^{\circledR} \mathrm{CCL}^{6} 2^{\mathrm{TM}}$ ) and Vero (African green monkey kidney normal epithelial, ATCC $^{\circledR} \mathrm{CCL}^{-}$ $81^{\mathrm{TM}}$ ) normal cells were kept in a suitable medium involving fetal bovine serum and antibiotic solution. The cell suspension was adjusted to $1 \times 10^{6}$ cells in $10 \mathrm{~mL}$ and transferred $100 \mu \mathrm{L}$ into the each well in culture plates. The compounds dissolved in sterile DMSO at $10-200 \mu \mathrm{g} / \mathrm{mL}$ final concentration were transferred to the cells and incubated at $37^{\circ} \mathrm{C}$ under $5 \% \mathrm{CO}_{2}$ atmosphere overnight. The cytotoxic activity of the Schiff bases was examined using MTT cell proliferation assay noted as percent inhibition. The percent inhibition calculated as shown below:

\%inhibition $=[1-($ Absorbance of Treatments $/$ Absorbance of DMSO $) \times 100]$.

The half maximal inhibitory concentration (IC50) of the compounds was noted in $\mu \mathrm{g} / \mathrm{mL}$ at 95 $\%$ confidence intervals. GI50 values were calculated by following:

$$
[(\mathrm{Ti}-\mathrm{Tz}) /(\mathrm{C}-\mathrm{Tz})] \times 100=50,
$$

which is the drug concentration bringing about a $50 \%$ reduction in the net growth in control cells in the course of the drug incubation.

Total growth inhibition (TGI) was calculated by $\mathrm{Ti}=\mathrm{Tz}$. The LC50 indicating a net loss of cells following treatment was calculated according to the formula below:

$$
[(\mathrm{Ti}-\mathrm{Tz}) / \mathrm{Tz}] \times 100=-50 .
$$

\section{Cytotoxicity Assay}

The cytotoxicity of the Schiff bases was determined by using the cytosolic LDH measurement kit. Into each well, $5 \times 10^{3}$ cells were conveyed as triplicates in order to expose to IC50 
concentrations of the test compounds and incubated at $37{ }^{\circ} \mathrm{C}$ under $5 \% \mathrm{CO}_{2}$ atmosphere overnight. The percentage cytotoxicity was obtained by the following equation:

(experimental value - low control / high control - low control) x 100,

in which experimental value is the test-compound treated cells, high control (maximum LDH release) is Triton $\mathrm{X}-100$ treated cells, low control (spontaneous LDH release) is the untreated cells.

\section{Cell imaging}

HeLa and C 6 cells were plated in 96-well plates at a density of 5.000 cells per well and awaited for $24 \mathrm{~h}$. The compound 3d in a concentration dependent manner was added and morphological changes of the cells were screened by phase contrast microscopy in every $6 \mathrm{~h}$ for $24 \mathrm{~h}$. Images of the treated and untreated cells were photographed after the completion of the process by an inverted microscope equipped with a digital camera.

\section{Statistical Analysis}

The statistical significance of the variations was determined by the one-way analyses of variance (one-way ANOVA) followed by Tukey's test. SPSS for Windows was used for statistical analyses.

\section{RESULTS AND DISCUSSION}

The Schiff bases were obtained by refluxing amino acid esters with salicylaldehyde derivatives in a chloroform medium under basic conditions. The condensation products were obtained in a couple of days with moderate to high yields. Azomethines were yellow oily compounds which did not need further purification. The compounds were soluble in common organic solvents (methanol, ethanol, $\mathrm{CHCl}_{3}, \mathrm{CH}_{2} \mathrm{Cl}_{2}$, etc.) Their structures were proved by elemental analysis and, UV-Vis, FT-IR, ${ }^{1} \mathrm{H}$ - and ${ }^{13} \mathrm{C}-\mathrm{NMR}$ spectroscopic methods.

\section{FT-IR and UV-Vis Spectra}

The positions of the important IR bands were shown in the experimental part and the FT-IR spectra of 3a was depicted in Figure 1. Sharp absorption bands between $1638-1626 \mathrm{~cm}^{-1}$ were ascribed to the $\mathrm{CH}=\mathrm{N}$ stretching bands for all of the Schiff bases. Aromatic hydroxy substituent participating in intramolecular hydrogen bonding with azomethine nitrogen atom was observed as a broad band about $3400 \mathrm{~cm}^{-1}$. The sharp absorption bands near $1740 \mathrm{~cm}^{-1}$ were related to the asymmetric carboxylate stretches ( $\mathrm{COO}$ ). The $\mathrm{Ph}-\mathrm{O}$ vibrations were observed around 1276$1221 \mathrm{~cm}^{-1}$. Symmetric and asymmetric aliphatic $\mathrm{C}-\mathrm{H}$ stretching bands were assigned to 2953$2837 \mathrm{~cm}^{-1}$ range. As it comes to aromatic $\mathrm{C}-\mathrm{H}$ protons, they could not be observed in $\mathbf{3 a - c}$ and 3g-i Schiff bases, however the FT-IR spectra of 3d-f Schiff bases exhibited aromatic proton 
stretching vibration peaks because of existence of aromatic protons of phenylalanine in addition to those of aldehyde part.

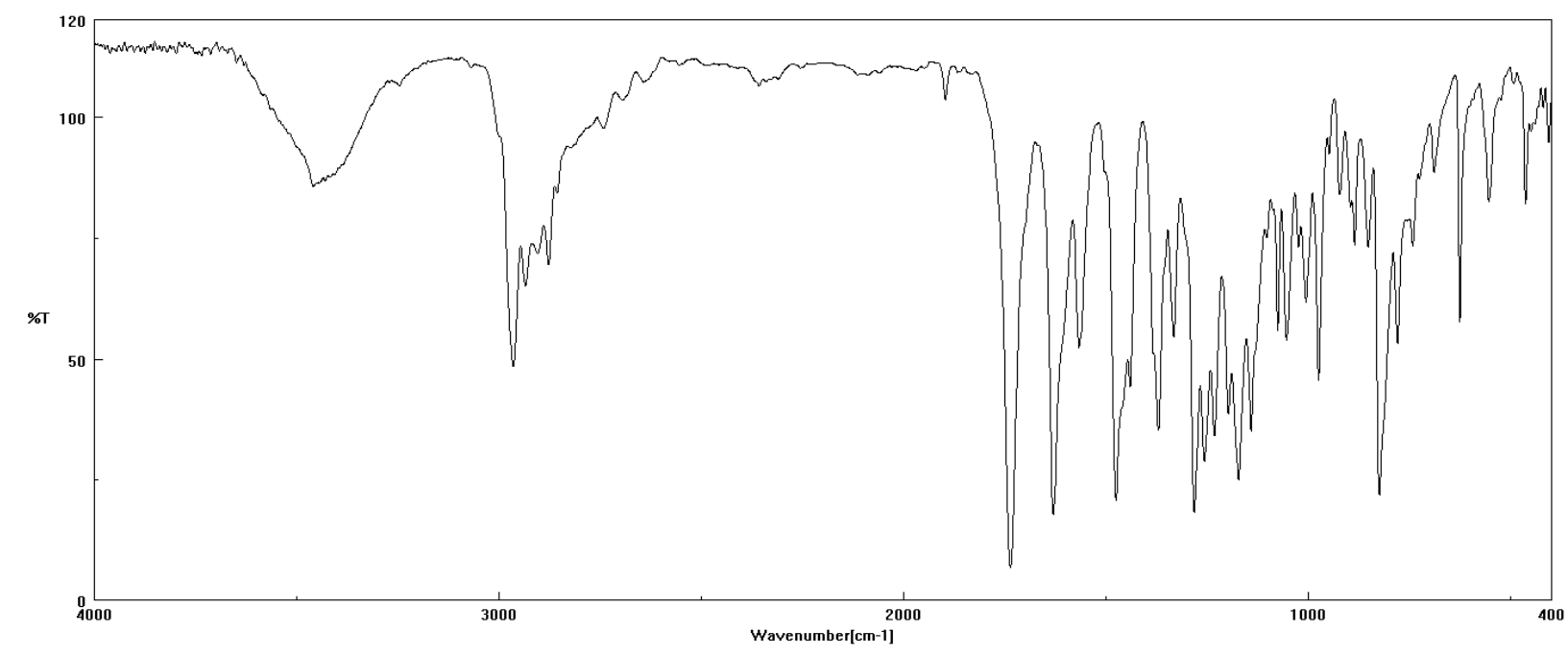

Figure 1: FT-IR spectrum of $\mathbf{3 a .}$

UV-Vis studies were also performed for all of the Schiff bases by dissolving in methanol. UV-Vis spectra exhibited three bands for all compounds as listed in Table 1.

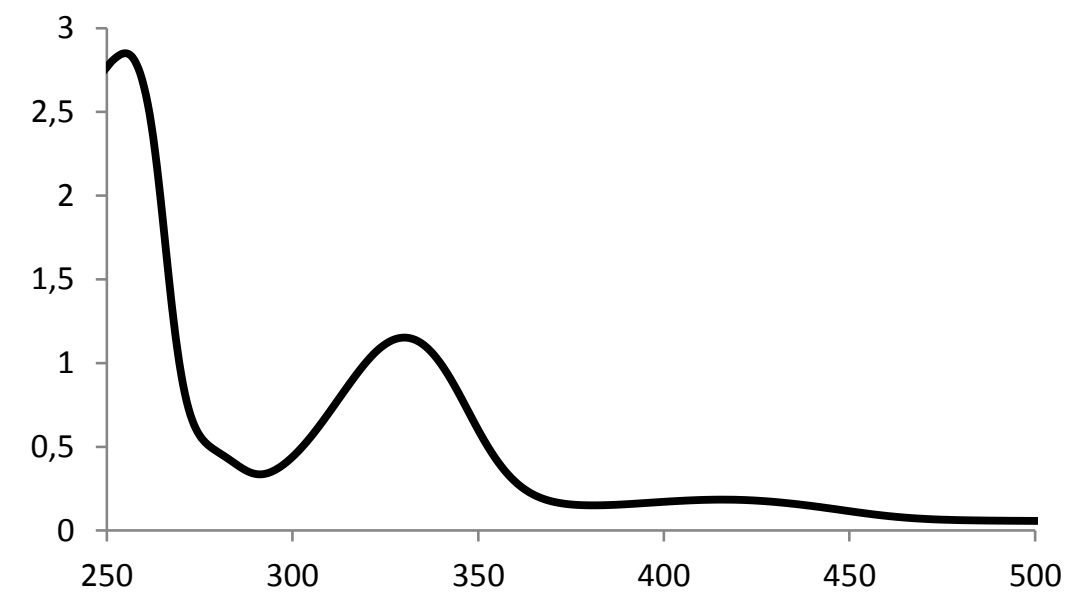

Figure 2: UV-Vis spectrum of $\mathbf{3 a .}$

A high energy band observed below $300 \mathrm{~nm}$ can be assigned to $\pi \rightarrow \pi^{*}$ transitions carried out in aromatic rings. The band at 376 and $379 \mathrm{~nm}$ in phenylalanine Schiff bases $\mathbf{3 b} \mathbf{b} \mathbf{3 e}$ and $\mathbf{3 h}$ can be sprung from charge transfer within the whole Schiff base molecule. That kind of band is caused by the strong intramolecular hydrogen bond between the hydroxyl and the azomethine group of o-hydroxyl Schiff bases (45). As it comes to the bands observed in the range of 327$424 \mathrm{~nm}$, they can be assigned to the $\mathrm{n} \rightarrow \pi^{*}$ transitions for the isoleucine and methionine Schiff bases. 


\section{${ }^{1} \mathbf{H}-$ and ${ }^{13} \mathrm{C}-\mathrm{NMR}$ Spectra}

The ${ }^{1} \mathrm{H}$ - and ${ }^{13} \mathrm{C}$-NMR spectra of all of the Schiff bases were consistent with the suggested structures. The ${ }^{1} \mathrm{H}$ - and ${ }^{13} \mathrm{C}$-NMR spectra for 3a were demonstrated in Figure 3. A singlet peak about $13.5 \mathrm{ppm}$ was attributed to the hydroxyl group of all imine compounds. The azomethine peak, an evidence for the Schiff base formation, was observed as a singlet in the range of 8.15$8.58 \mathrm{ppm}$. Methoxy group belonging to the amino acid ester induced to a singlet about 3.65 ppm. Aromatic ring protons were observed at 6.20-7.71 ppm as doublets and triplets for isoleucine (3a-c) and methionine (3g-i) Schiff bases. Same protons appeared in the similar region, but as overlapped with aromatic protons of phenylalanine for the Schiff bases $\mathbf{3 d - f}$. As it comes to aliphatic protons, they were observed in characteristic methyl, methylene and methyne region as shown in the experimental.

\section{BIOLOGICAL ACTIVITY}

\section{Antiproliferative Actions of the Compounds}

The antiproliferative activities of the Schiff bases and positive control against cell lines were screened according to a cell proliferation assay performed by using the 3-(4,5-dimethylthiazol2-yl)-2,5-diphenyltetrazolium bromide (MTT). The antiproliferative actions and selectivity of the Schiff bases were evaluated through tumor cells and normal cells (Vero and FL). Also, statistically significant differences $(P<0.05)$ attracted the attention among cancer cell lines compared to normal cell lines for the different concentrations. According to TGI and IC50 values in Table 2, 3d displayed very strong cytotoxic activity than the control drugs, 5-fluorouracil and cisplatin, on all cancer cell lines (TGI 5.81-52.36 $\mathrm{g} / \mathrm{mL}$, IC50 5.72-46.35), except for A549. Compounds 3c, 3e, 3h and 3i were effective on HeLa (TGI $44.24 \mu \mathrm{g} / \mathrm{mL}$, IC50 $41.99 \pm 2.9 \mu \mathrm{g} / \mathrm{mL}$ ), HT29 (TGI $28.19 \mu \mathrm{g} / \mathrm{mL}$, IC50 $18.58 \pm 3.4 \mu \mathrm{g} / \mathrm{mL}$ ), and C6 (TGI $38.70 \mu \mathrm{g} / \mathrm{mL}$, IC50 $36.33 \pm 3.8$ for $3 \mathbf{h}$ and TGI $3.75 \mu \mathrm{g} / \mathrm{mL}$, IC50 $3.69 \pm 2.7 \mu \mathrm{g} / \mathrm{mL}$ for $\mathbf{3 i}$ ) cell lines, respectively (Table 2-4) (Figure 4). For HeLa and HT29 cell lines, compounds $\mathbf{3 a}, \mathbf{3 b}, \mathbf{3 f}$, and $\mathbf{3 g}$ had remarkable TGI values (Table 3-4). The IC50 values of the $\mathbf{3 a}, \mathbf{3 b} \mathbf{3} \mathbf{3 f}$, and $\mathbf{3 g}$ (2.79-23.31, 12.49-64.17, 21.98-26.59, and $6.27-89.89 \mu \mathrm{g} / \mathrm{mL}$, respectively) for these two cancer lines were similar to the TGI parameters. 3a and 3b also had potent cytotoxic activity on C6 cells (TGI 5.63, IC50 5.42 and TGI 7.59, IC50 $7.49 \mu \mathrm{g} / \mathrm{mL}$, respectively) (Table 3-4) (Figure 4). For C6 cells, compounds 3b, 3d and 3i had remarkable LC50 values (37.21, 26.76 and $17.39 \mu \mathrm{g} / \mathrm{mL}$, respectively) (Figure 4). However, the LC50 values of compounds $\mathbf{3 a}$ and $\mathbf{3 g}$ were only meaningful for HeLa cell line (11.09 and $29.73 \mu \mathrm{g} / \mathrm{mL}$, respectively) (Tables 2-4) (Figure 4). Compound 3a had the best GI50 values $(1.55,1.93$, and $1.78 \mu \mathrm{g} / \mathrm{mL}$, respectively) when it came to the HeLa, MCF7, and C6 cell lines. In addition, compound $\mathbf{3 d}$ and $\mathbf{3 e}$ had remarkable GI50 values (1.68 and $1.84 \mu \mathrm{g} / \mathrm{mL}$, respectively) for MCF7 cell line. Compound 3i exhibited significant GI50 value $(1.84 \mu \mathrm{g} / \mathrm{mL})$ for c6 cell line. 
Akkuş Taş N, Şenocak A and Aydın A. JOTCSA. 2018;5(2): 585-606.

Table 1: UV-Vis spectral data for the Schiff bases in methanol.

\begin{tabular}{|c|c|c|}
\hline Compound & \multicolumn{2}{|c|}{$\lambda(\mathrm{nm})$} \\
\hline $3 a$ & $\begin{array}{l}255 \\
33\end{array}$ & 416 \\
\hline 3b & $\begin{array}{l}282 \\
307\end{array}$ & 376 \\
\hline 3c & $\begin{array}{l}265 \\
327\end{array}$ & 423 \\
\hline 3d & $\begin{array}{l}255 \\
330\end{array}$ & 418 \\
\hline $3 e$ & $\begin{array}{l}282 \\
310\end{array}$ & 379 \\
\hline $3 f$ & $\begin{array}{l}264 \\
328\end{array}$ & 423 \\
\hline $3 \mathbf{g}$ & $\begin{array}{l}255 \\
330\end{array}$ & 410 \\
\hline 3h & $\begin{array}{l}282 \\
310\end{array}$ & 376 \\
\hline $3 \mathbf{i}$ & $\begin{array}{l}265 \\
330\end{array}$ & 424 \\
\hline
\end{tabular}

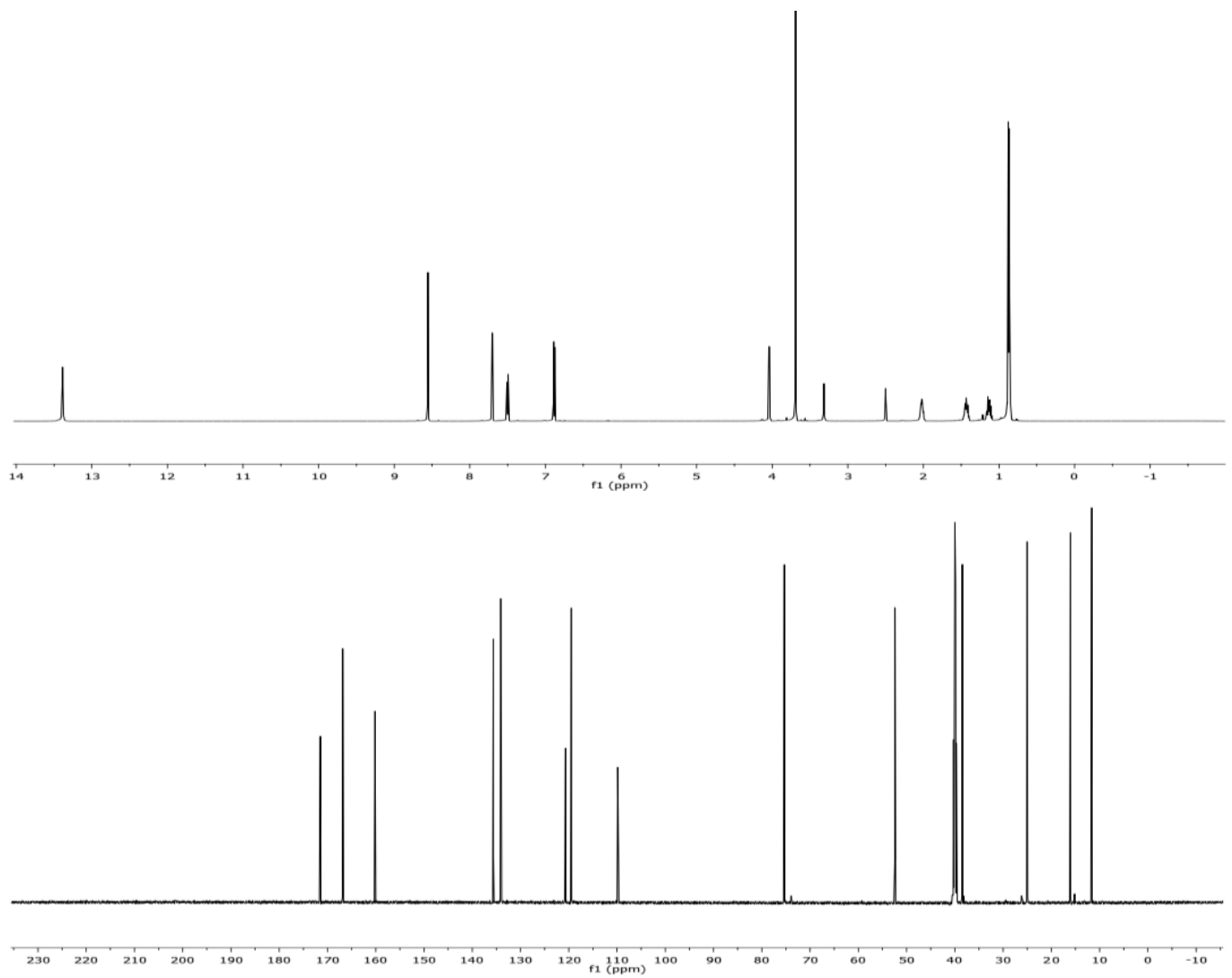

Figure 3: ${ }^{1} \mathrm{H}$ - and ${ }^{13} \mathrm{C}-\mathrm{NMR}$ spectra of $\mathbf{3 a}$. 
Table 2: GI50, TGI, LC50 and IC50 values for $\mathbf{3 a}$, $\mathbf{3 b}$, and $\mathbf{3 c}$.

\begin{tabular}{|c|c|c|c|c|c|c|c|c|c|c|c|c|}
\hline \multirow{2}{*}{$\mu g / m L$} & \multicolumn{4}{|c|}{$3 a$} & \multicolumn{4}{|c|}{$3 b$} & \multicolumn{4}{|c|}{$3 c$} \\
\hline & GI50 & TGI & LC50 & IC50 & GI50 & TGI & LC50 & IC50 & GI50 & TGI & LC50 & IC50 \\
\hline A549 & $\begin{array}{l}68.49 \\
\pm 8.34\end{array}$ & $>10000$ & $>10000$ & $>10000$ & $\begin{array}{c}104.53 \\
\pm 8.4\end{array}$ & $>10000$ & $>10000$ & $>10000$ & $\begin{array}{c}18.89 \\
\pm 1.0\end{array}$ & $>10000$ & $>10000$ & $>10000$ \\
\hline HeLa & $\begin{array}{c}1.55 \pm \\
0.08\end{array}$ & $\begin{array}{c}2.80 \pm 0 \\
08\end{array}$ & $\begin{array}{c}11.09 \pm 0 \\
.77\end{array}$ & $\begin{array}{c}2.79 \pm 0 \\
07\end{array}$ & $\begin{array}{c}2.92 \pm 0 \\
.21\end{array}$ & $\begin{array}{c}12.70 \pm 0 \\
.64\end{array}$ & $\begin{array}{c}416.42 \pm \\
15.3\end{array}$ & $\begin{array}{c}12.49 \pm 0 \\
.71\end{array}$ & $\begin{array}{c}2.64 \pm \\
0.12\end{array}$ & $\begin{array}{c}44.24 \pm 3 \\
.7\end{array}$ & $>10000$ & $\begin{array}{c}41.99 \pm 3 \\
.1\end{array}$ \\
\hline HT29 & $\begin{array}{c}4.18 \pm \\
0.17\end{array}$ & $\begin{array}{c}28.39 \pm 1 \\
.3\end{array}$ & $\begin{array}{c}2504.05 \\
\pm 51.9\end{array}$ & $\begin{array}{c}23.31 \pm 0 \\
.89\end{array}$ & $\begin{array}{c}3.79 \pm 0 \\
.25\end{array}$ & $\begin{array}{c}115.02 \pm \\
7.9\end{array}$ & $>10000$ & $\begin{array}{c}64.17 \pm 4 \\
.3\end{array}$ & & $\begin{array}{c}3613.74 \\
\pm 54.6\end{array}$ & $>10000$ & $\begin{array}{c}702.60 \pm \\
28.3\end{array}$ \\
\hline Нер3в & $\begin{array}{c}3.81 \pm \\
0.11\end{array}$ & $\begin{array}{c}1316.12 \\
\pm 47.5\end{array}$ & $>10000$ & $\begin{array}{c}1133.57 \\
\pm 33.9\end{array}$ & $\begin{array}{c}6.53 \pm 0 \\
.37\end{array}$ & $>10000$ & $>10000$ & $>10000$ & $\begin{array}{c}5.11 \pm \\
0.43\end{array}$ & $>10000$ & $>10000$ & $>10000$ \\
\hline MCF7 & $\begin{array}{c}1.93 \pm \\
0.09\end{array}$ & $\begin{array}{c}1296.89 \\
\pm 42.8\end{array}$ & $>10000$ & $\begin{array}{c}904.30 \pm \\
28.4\end{array}$ & $\begin{array}{c}2.68 \pm 0 \\
.29\end{array}$ & $\begin{array}{c}4169.61 \\
\pm 61.7\end{array}$ & $>10000$ & $\begin{array}{c}2833.66 \\
\pm 59.2\end{array}$ & $\begin{array}{c}1.68 \pm \\
0.08\end{array}$ & $\begin{array}{c}2099.80 \\
\pm 72.3\end{array}$ & $>10000$ & $\begin{array}{c}1347.86 \\
\pm 54.8\end{array}$ \\
\hline C6 & $\begin{array}{c}1.78 \pm \\
0.09\end{array}$ & $\begin{array}{c}5.63 \pm 0 \\
46\end{array}$ & $\begin{array}{c}176.18 \pm \\
14.5\end{array}$ & $\begin{array}{c}5.42 \pm 0 \\
18\end{array}$ & $\begin{array}{c}3.11 \pm 0 \\
.20\end{array}$ & $\begin{array}{c}7.59 \pm 0 . \\
76\end{array}$ & $\begin{array}{c}37.21 \pm 2 \\
.1\end{array}$ & $\begin{array}{c}7.49 \pm 0 \\
33\end{array}$ & $\begin{array}{c}5.32 \pm \\
0.51\end{array}$ & $\begin{array}{c}5675.32 \\
\pm 71.4\end{array}$ & $>10000$ & $\begin{array}{c}3796,80 \\
\pm 65.4\end{array}$ \\
\hline Vero & $\begin{array}{c}3.50 \pm \\
0.21\end{array}$ & $\begin{array}{c}10.55 \pm 0 \\
.98\end{array}$ & $\begin{array}{c}83.99 \pm 1 \\
1.0\end{array}$ & $\begin{array}{c}10.26 \pm 0 \\
.34\end{array}$ & $\begin{array}{c}2.43 \pm 0 \\
.19\end{array}$ & $\begin{array}{c}115.33 \pm \\
5.6\end{array}$ & $>10000$ & $\begin{array}{c}92.31 \pm 5 \\
.32\end{array}$ & $\begin{array}{l}4.03 \pm \\
0.36\end{array}$ & $\begin{array}{c}248.67 \pm \\
17.9\end{array}$ & $>10000$ & $\begin{array}{c}195.66 \pm \\
15.8\end{array}$ \\
\hline $\mathbf{F L}$ & $\begin{array}{c}4.21 \pm \\
0.27\end{array}$ & $\begin{array}{c}31.57 \pm 1 \\
.4\end{array}$ & $\begin{array}{c}3977.09 \\
\pm 71.4 \\
\end{array}$ & $\begin{array}{c}30.91 \pm 1 \\
.5 \\
\end{array}$ & $\begin{array}{c}3.63 \pm 0 \\
.27 \\
\end{array}$ & $\begin{array}{c}19.90 \pm 2 \\
.7 \\
\end{array}$ & $\begin{array}{c}1020.77 \\
\pm 22.6 \\
\end{array}$ & $\begin{array}{c}19.54 \pm 1 \\
.4\end{array}$ & $\begin{array}{c}4.14 \pm \\
0.37\end{array}$ & $\begin{array}{c}2736.46 \\
\pm 65.1 \\
\end{array}$ & $>10000$ & $\begin{array}{c}2394.84 \\
\pm 69.1 \\
\end{array}$ \\
\hline
\end{tabular}

Values are given as the mean \pm SD of three experiments and $r^{2}=0.86$ to 0.97 . Significant at $P<0.05$

Table 3: GI50, TGI, LC50 and IC50 values for 3d, 3e, and 3f.

\begin{tabular}{|c|c|c|c|c|c|c|c|c|c|c|c|c|}
\hline \multirow{2}{*}{$\mu g / m L$} & \multicolumn{4}{|c|}{$3 d$} & \multicolumn{4}{|c|}{$3 e$} & \multicolumn{4}{|c|}{$3 f$} \\
\hline & GI50 & TGI & LC50 & IC50 & GI50 & TGI & LC50 & IC50 & GI50 & TGI & LC50 & IC50 \\
\hline A549 & $\begin{array}{c}74.49 \\
\pm 4.3\end{array}$ & $>10000$ & $>10000$ & $>10000$ & $\begin{array}{c}152.22 \\
\pm 9.7\end{array}$ & $>10000$ & $>10000$ & $>10000$ & $\begin{array}{c}32.98 \\
\pm 1.2\end{array}$ & $>10000$ & $>10000$ & $>10000$ \\
\hline HeLa & $\begin{array}{c}3.06 \pm \\
0.41\end{array}$ & $\begin{array}{c}13.63 \pm \\
0.49\end{array}$ & $\begin{array}{c}442.07 \pm \\
21.0\end{array}$ & $\begin{array}{c}13.39 \pm \\
0.77\end{array}$ & $\begin{array}{c}3.59 \pm 0 \\
.63\end{array}$ & $\begin{array}{c}108.90 \\
\pm 9.1\end{array}$ & $>10000$ & $\begin{array}{c}102.28 \pm \\
5.7\end{array}$ & $\begin{array}{c}3.28 \pm \\
0.54\end{array}$ & $\begin{array}{c}22.56 \pm \\
0.87\end{array}$ & $\begin{array}{c}3513.62 \\
\pm 71.6\end{array}$ & $\begin{array}{c}21.98 \pm 0 \\
.88\end{array}$ \\
\hline HT29 & $\begin{array}{c}2.63 \pm \\
0.22\end{array}$ & $\begin{array}{c}14.97 \pm \\
0.41\end{array}$ & $\begin{array}{c}1933.71 \\
\pm 59.7\end{array}$ & $\begin{array}{c}12.01 \pm \\
0.63\end{array}$ & $\begin{array}{c}2.48 \pm 0 \\
.57\end{array}$ & $\begin{array}{c}28.19 \pm \\
0.93\end{array}$ & $>10000$ & $\begin{array}{c}18.58 \pm 1 \\
.1\end{array}$ & $\begin{array}{c}3.29 \pm \\
0.21\end{array}$ & $\begin{array}{c}36.87 \pm \\
0.93\end{array}$ & $>10000$ & $\begin{array}{c}26.59 \pm 0 \\
.87\end{array}$ \\
\hline Hep3B & $\begin{array}{c}3.07 \pm \\
0.37\end{array}$ & $\begin{array}{c}30.62 \pm \\
0.97\end{array}$ & $>10000$ & $\begin{array}{c}29.55 \pm \\
1.5\end{array}$ & $\begin{array}{c}4.67 \pm 0 \\
.45\end{array}$ & $>10000$ & $>10000$ & $>10000$ & $\begin{array}{c}7.13 \pm \\
0.48\end{array}$ & $>10000$ & $>10000$ & $>10000$ \\
\hline MCF7 & $\begin{array}{c}2.19 \pm \\
0.33\end{array}$ & $\begin{array}{c}52.36 \pm \\
1.4\end{array}$ & $>10000$ & $\begin{array}{c}46.35 \pm \\
1.7\end{array}$ & $\begin{array}{c}1.84 \pm 0 \\
.24\end{array}$ & $\begin{array}{c}814.18 \\
\pm 19.2\end{array}$ & $>10000$ & $\begin{array}{c}581.23 \pm \\
17.8\end{array}$ & $\begin{array}{c}3.96 \pm \\
0.27\end{array}$ & $>10000$ & $>10000$ & $>10000$ \\
\hline C6 & $\begin{array}{c}2.56 \pm \\
0.31\end{array}$ & $\begin{array}{c}5.81 \pm 0 \\
37\end{array}$ & $\begin{array}{c}26.76 \pm 1 \\
.0\end{array}$ & $\begin{array}{c}5.72 \pm 0 \\
19\end{array}$ & $\begin{array}{c}9.61 \pm 0 \\
.61\end{array}$ & $>10000$ & $>10000$ & $\begin{array}{c}7380.55 \\
\pm 51.0\end{array}$ & $\begin{array}{c}4.13 \pm \\
0.18\end{array}$ & $\begin{array}{c}2897.4 \\
\pm 62.7\end{array}$ & $>10000$ & $\begin{array}{c}1962.94 \\
\pm 21.3\end{array}$ \\
\hline Vero & $\begin{array}{c}2.34 \pm \\
0.34\end{array}$ & $\begin{array}{c}12.43 \pm \\
0.42\end{array}$ & $\begin{array}{c}1740.98 \\
\pm 44.0\end{array}$ & $\begin{array}{c}11.61 \pm \\
0.23\end{array}$ & $\begin{array}{c}4.64 \pm 0 \\
.42\end{array}$ & $\begin{array}{c}100.54 \\
\pm 8.7\end{array}$ & $>10000$ & $\begin{array}{c}86.56 \pm 5 \\
.9\end{array}$ & $\begin{array}{c}3.76 \pm \\
0.19\end{array}$ & $\begin{array}{c}36.31 \pm \\
0.99\end{array}$ & $>10000$ & $\begin{array}{c}32.89 \pm 1 \\
.1\end{array}$ \\
\hline $\mathbf{F L}$ & $\begin{array}{c}3.58 \pm \\
0.33\end{array}$ & $\begin{array}{c}20.70 \pm \\
0.88\end{array}$ & $\begin{array}{c}1327.85 \\
\pm 42.5 \\
\end{array}$ & $\begin{array}{c}20.31 \pm \\
0.41 \\
\end{array}$ & $\begin{array}{c}4.20 \pm 0 \\
.39 \\
\end{array}$ & $\begin{array}{c}66.21 \pm \\
4.3 \\
\end{array}$ & $>10000$ & $\begin{array}{c}63.61 \pm 5 \\
.3 \\
\end{array}$ & $\begin{array}{c}5.53 \pm \\
0.34\end{array}$ & $\begin{array}{c}265.96 \\
\pm 8.6 \\
\end{array}$ & $>10000$ & $\begin{array}{c}250.97 \pm \\
7.4 \\
\end{array}$ \\
\hline
\end{tabular}

Values are given as the mean \pm SD of three experiments and $r^{2}=0.86$ to 0.97 . Significant at $P<0.05$ 
Table 4: GI50, TGI, LC50 and IC50 values for $\mathbf{3 g}, \mathbf{3 h}$, and $\mathbf{3 i}$.

\begin{tabular}{|c|c|c|c|c|c|c|c|c|c|c|c|c|}
\hline \multirow{2}{*}{$\mu g / m L$} & \multicolumn{4}{|c|}{$3 g$} & \multicolumn{4}{|c|}{$3 h$} & \multicolumn{4}{|c|}{$3 i$} \\
\hline & GI50 & TGI & LC50 & IC50 & GI50 & TGI & LC50 & IC50 & GI50 & TGI & LC50 & IC50 \\
\hline A549 & $\begin{array}{c}145.66 \pm \\
14.7\end{array}$ & $>10000$ & $>10000$ & $>10000$ & $\begin{array}{c}27.42 \pm \\
1.2\end{array}$ & $>10000$ & $>10000$ & $>10000$ & $\begin{array}{l}26.43 \\
\pm 0.97\end{array}$ & $>10000$ & $>10000$ & $>10000$ \\
\hline HeLa & $\begin{array}{c}2.72 \pm \\
0.09\end{array}$ & $\begin{array}{c}6.31 \pm 0 \\
.30\end{array}$ & $\begin{array}{c}29.73 \\
\pm 1.7\end{array}$ & $\begin{array}{c}6.27 \pm \\
0.43\end{array}$ & $\begin{array}{c}5.36 \pm \\
0.52\end{array}$ & $\begin{array}{c}3123.2 \\
\pm 57.8\end{array}$ & $>10000$ & $\begin{array}{c}2708.12 \\
\pm 59.2\end{array}$ & $\begin{array}{c}3.75 \pm \\
0.44\end{array}$ & $\begin{array}{c}116.36 \\
\pm 5.4\end{array}$ & $>10000$ & $\begin{array}{c}108.75 \pm \\
9.8\end{array}$ \\
\hline HT29 & $\begin{array}{c}3.71 \pm \\
0.13\end{array}$ & $\begin{array}{c}160.88 \pm \\
15.2\end{array}$ & $>10000$ & $\begin{array}{c}89.89 \pm \\
11.4\end{array}$ & $\begin{array}{c}2.56 \pm \\
0.43\end{array}$ & $>10000$ & $>10000$ & $>10000$ & $\begin{array}{c}2.86 \pm \\
0.11\end{array}$ & $\begin{array}{c}1193.61 \\
\pm 14.9\end{array}$ & $>10000$ & $\begin{array}{c}268.47 \pm \\
10.1\end{array}$ \\
\hline Нер3в & $\begin{array}{c}4.42 \pm \\
0.22\end{array}$ & $\begin{array}{c}996.31 \pm \\
37.8\end{array}$ & $>10000$ & $\begin{array}{c}874.91 \\
\pm 32.1\end{array}$ & $\begin{array}{c}2.74 \pm \\
0.37\end{array}$ & $>10000$ & $>10000$ & $>10000$ & $\begin{array}{c}7.23 \pm \\
0.28\end{array}$ & $>10000$ & $>10000$ & $>10000$ \\
\hline MCF7 & $\begin{array}{c}2.15 \pm \\
0.14\end{array}$ & $\begin{array}{c}374.11 \pm \\
24.7\end{array}$ & $>10000$ & $\begin{array}{c}293.37 \\
\pm 17.4\end{array}$ & $\begin{array}{c}3.09 \pm \\
0.39\end{array}$ & $\begin{array}{c}2657.17 \\
\pm 54.6\end{array}$ & $>10000$ & $\begin{array}{c}1903.43 \\
\pm 51.3\end{array}$ & $\begin{array}{c}2.43 \pm \\
0.14\end{array}$ & $>10000$ & $>10000$ & $>10000$ \\
\hline C6 & $\begin{array}{c}4.79 \pm \\
0.25\end{array}$ & $>10000$ & $>10000$ & $>10000$ & $\begin{array}{c}4.98 \pm \\
0.40\end{array}$ & $\begin{array}{c}38.70 \pm \\
1.6\end{array}$ & $\begin{array}{c}4110.5 \\
\pm 67.4\end{array}$ & $\begin{array}{c}36.33 \pm \\
1.1\end{array}$ & $\begin{array}{c}1.84 \pm \\
0.07\end{array}$ & $\begin{array}{c}3.75 \pm \\
0.19\end{array}$ & $\begin{array}{c}17.39 \pm \\
2.2\end{array}$ & $\begin{array}{c}3.69 \pm \\
0.55\end{array}$ \\
\hline Vero & $\begin{array}{c}4.06 \pm \\
0.31\end{array}$ & $\begin{array}{c}17.57 \pm \\
1.7\end{array}$ & $\begin{array}{c}349.06 \pm \\
27.6\end{array}$ & $\begin{array}{c}16.84 \pm \\
0.49\end{array}$ & $\begin{array}{c}3.00 \pm \\
0.35\end{array}$ & $>10000$ & $>10000$ & $>10000$ & $\begin{array}{c}3.35 \pm \\
0.34\end{array}$ & $\begin{array}{c}647.63 \pm \\
13.5\end{array}$ & $>10000$ & $\begin{array}{c}452.61 \pm \\
12.7\end{array}$ \\
\hline FL & $\begin{array}{c}3.43 \pm \\
0.27\end{array}$ & $\begin{array}{c}26.20 \pm \\
1.8 \\
\end{array}$ & $\begin{array}{c}5663.91 \\
\pm 77.3 \\
\end{array}$ & $\begin{array}{c}25.60 \pm \\
1.0 \\
\end{array}$ & $\begin{array}{c}5.06 \pm \\
0.46\end{array}$ & $>10000$ & $>10000$ & $\begin{array}{c}9447.3 \\
\pm 71.4 \\
\end{array}$ & $\begin{array}{c}6.82 \pm \\
0.95 \\
\end{array}$ & $\begin{array}{c}1625.41 \\
\pm 37.2 \\
\end{array}$ & $>10000$ & $\begin{array}{c}1475.11 \\
\pm 47.6 \\
\end{array}$ \\
\hline
\end{tabular}

Values are given as the mean \pm SD of three experiments and $r^{2}=0.86$ to 0.97 . Significant at $P<0.05$ 
Some cancer cells were more sensitive to the tested Schiff bases than FL and Vero normal cells. A comparison of the activities of these compounds in regard to the IC50 values as against normal cells (FL and Vero) revealed the following: 3d, 3e, 3h for HT29, 3a, 3b, 3c, 3d, 3e, 3f, 3g for HeLa and $\mathbf{3 a}, \mathbf{3 b}, \mathbf{3} \mathbf{d}, \mathbf{3 h}, \mathbf{3 i}$ for $\mathrm{c} 6$ were more selective than others. Hence, the findings significantly highlight some compounds as possible selective antiproliferative agents for some cancer types. The pharmacological activities of these compounds are probably due to the major bioactive substituents such as hydroxy, methoxy, phenyl, methylthio, and bromine. Especially, bromine group may be responsible for cytotoxic activities of $\mathbf{3 a}, \mathbf{3 d}$ and $\mathbf{3 g}$ having the highest pharmacological activity against cancer cells. The higher antiproliferative activity of compound 3d than 3a points out the importance of the phenyl substituent on cytotoxic activity. Overall, the high cytotoxic effects of these compounds may be related to their unique three-dimensional structures arising from the substituents. It was noted that three parameters (GI50, TGI, LC50) of these compounds met NCI-60 criteria enough to pass into further pharmacological investigations.
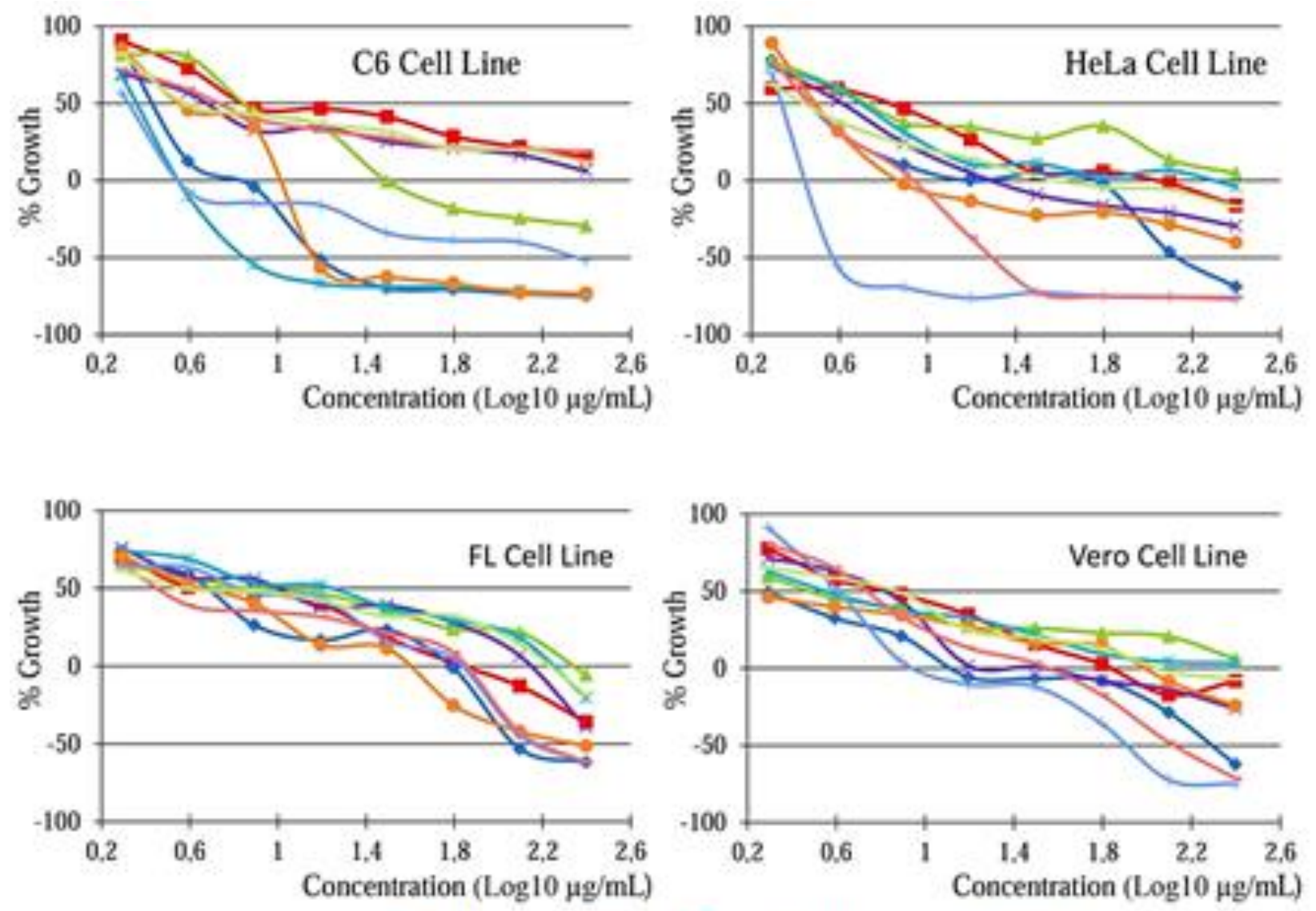

$$
-3 a \rightarrow-3 b-3 c \rightarrow 3 d-3 e+3 f-3 g-3 h-3 i
$$

Figure 4: Effects of the compounds on the proliferation of $\mathrm{C} 6$, HeLa, $\mathrm{FL}$, and Vero cells. Exponentially growing cells were incubated with the Schiff bases for 24 hours. 
Table 5: IC50 $(\mu \mathrm{g} / \mathrm{mL})$ of positive controls in cell lines.

\begin{tabular}{lcccccccc}
\hline & HeLa & HT29 & A549 & MCF7 & C6 & Hep3B & FL & Vero \\
\hline \multirow{2}{*}{ Cisplatin } & $50.29 \pm$ & $40.39 \pm$ & $60.49 \pm$ & $63.79 \pm$ & $33.08 \pm$ & $48.69 \pm$ & $52.79 \pm$ & $56.20 \pm$ \\
& 8.3 & 5.6 & 8.5 & 7.4 & 4.8 & 5.3 & 6.0 & 5.3 \\
& $61.59 \pm$ & $65.19 \pm$ & $69.79 \pm$ & $74.19 \pm$ & $54.30 \pm$ & $62.89 \pm$ & $59.09 \pm$ & $65.35 \pm$ \\
5FU & 7.1 & 5.3 & 8.1 & 8.0 & 7.3 & 6.8 & 6.4 & 5.9 \\
\hline
\end{tabular}

\section{Cytotoxic Mode of the Compounds}

Cytotoxic activities of the Schiff bases $(25,50,75$, and $100 \mu \mathrm{g} / \mathrm{mL})$ on cell lines were monitored by the LDH cytotoxicity kit. The \%cytotoxicity values of these compounds at concentration of 25 $\mathrm{\mu g} / \mathrm{mL}$ were in the range of $6.21 \%-34.74 \%$ against all cell lines. Compound $\mathbf{3 b}$ caused the most powerful cytotoxic effect $(34.71 \%, \mathrm{p}<0.05)$ against $\mathrm{C} 6$ cell when compared to the other compounds and cell lines (Table 7). Compound $\mathbf{3 e}$ had the lowest percentage cytotoxicity with the values of 10.45\% (A549) and 23.31\% (C6) (Tables 6 and 7) (Figure 5). Compound 3c also exhibited the smallest percentage cytotoxicity for HeLa $(8.11 \%)$ and FL $(14.88 \%)$ cells. Compound $\mathbf{3} \mathbf{i}$, the condensation product of methionine methyl ester and o-vanilin, was interestingly highly toxic for A549 and HT29 cells (22.80\% and $32.68 \%$, respectively), whereas less toxic for Hep3B and Vero cells (8.36\% and $11.91 \%$, respectively) (Tables 6-8) (Figure 5). Similarly, 3b, composed of isoleucine methyl ester and 2,4-dihydroxybenzaldehyde, was very toxic for C6 (34.71\%) and less toxic for HT29 (16.34\%). However, 3i and 3b may cause cytotoxic effect via the same mechanisms of action. It is noteworthy that the compound $\mathbf{3 f}$, containing phenylalanine methyl ester and o-vanilin, had slightly high toxicity against MCF7, Vero, and FL cells (11.91\%, 23.69\%, and 29.32\%, respectively) than the other compounds which had similar potent cytotoxic activity. Compound $\mathbf{3 h}$ exhibited the lowest percentage cytotoxicity for MCF7 cell lines. The rest of the compounds (3a and $\mathbf{3 d}$ ) had the highest cytotoxic effect towards HeLa and Hep3B cells (31.22\% and 19.57, respectively). One of the most important conditions for being an anticancer agent is the minimal toxicity against normal cells. Therefore, cytotoxic features were compared in order to find out the advanced pharmacological capacities of these compounds. Compounds 3c (for HeLa, 8.11\%), 3e (for A549, 10.45\%), 3h (for MCF7, 6.21\%), and 3i (for Hep3B and Vero, $8.36 \%$ and $11.91 \%$, respectively) exhibited equal cytotoxicity with controls, indicating their significant antiproliferative potential as well as low cytotoxicity (Tables 6-9). 
Table 6: \% Cytotoxicity of the compounds against A549, HeLa, and HT29.

\begin{tabular}{|c|c|c|c|c|c|c|c|c|c|c|c|c|}
\hline \multirow{2}{*}{ \%Cytotoxicity } & \multicolumn{4}{|c|}{$A 549$} & \multicolumn{4}{|c|}{ HeLa } & \multicolumn{4}{|c|}{ HT29 } \\
\hline & $25 \mu \mathrm{g} / \mathrm{mL}$ & $50 \mu \mathrm{g} / \mathrm{mL}$ & $75 \mu \mathrm{g} / \mathrm{mL}$ & $100 \mu \mathrm{g} / \mathrm{mL}$ & $25 \mu \mathrm{g} / \mathrm{mL}$ & $50 \mu \mathrm{g} / \mathrm{mL}$ & $75 \mu \mathrm{g} / \mathrm{mL}$ & $100 \mu \mathrm{g} / \mathrm{mL}$ & $25 \mu \mathrm{g} / \mathrm{mL}$ & $50 \mu \mathrm{g} / \mathrm{mL}$ & $75 \mu \mathrm{g} / \mathrm{mL}$ & $100 \mu \mathrm{g} / \mathrm{mL}$ \\
\hline $3 \mathbf{a}$ & $\begin{array}{c}17,73 \pm \\
1.3\end{array}$ & $\begin{array}{c}26,85 \pm \\
1.9\end{array}$ & $\begin{array}{c}50,73 \pm \\
3.7\end{array}$ & $\begin{array}{c}60,67 \pm \\
4.3\end{array}$ & $\begin{array}{c}31,22 \pm \\
1.6\end{array}$ & $\begin{array}{c}68,90 \pm \\
1.7\end{array}$ & $\begin{array}{c}77,71 \pm \\
2.7\end{array}$ & $\begin{array}{c}103,86 \pm \\
5.1\end{array}$ & $\begin{array}{c}23,12 \pm \\
1.4\end{array}$ & $\begin{array}{c}52,44 \pm \\
2.9\end{array}$ & $\begin{array}{c}70,17 \pm \\
3.5\end{array}$ & $\begin{array}{c}89,74 \pm \\
3.9\end{array}$ \\
\hline $3 \mathbf{b}$ & $\begin{array}{c}17,54 \pm \\
1.4\end{array}$ & $\begin{array}{c}24,07 \pm \\
2.1\end{array}$ & $\begin{array}{c}43,64 \pm \\
3.1\end{array}$ & $\begin{array}{c}53,45 \pm \\
3.9\end{array}$ & $\begin{array}{c}18,94 \pm \\
1.4\end{array}$ & $\begin{array}{c}34,96 \pm \\
1.5\end{array}$ & $\begin{array}{c}53,07 \pm \\
2.1\end{array}$ & $\begin{array}{c}58,45 \pm \\
2.4\end{array}$ & $\begin{array}{c}16,34 \pm \\
1.1\end{array}$ & $\begin{array}{c}54,34 \pm \\
2.5\end{array}$ & $\begin{array}{c}80,24 \pm \\
3.7\end{array}$ & $\begin{array}{c}100,63 \pm \\
4.9\end{array}$ \\
\hline $3 c$ & $\begin{array}{c}15,64 \pm \\
1.4\end{array}$ & $\begin{array}{c}27,61 \pm \\
1.8\end{array}$ & $\begin{array}{c}47,44 \pm \\
2.9\end{array}$ & $\begin{array}{c}71,56 \pm \\
4.4\end{array}$ & $\begin{array}{c}8,11 \pm \\
0.8\end{array}$ & $\begin{array}{c}18,43 \pm \\
1.2\end{array}$ & $\begin{array}{c}36,10 \pm \\
1.8\end{array}$ & $\begin{array}{c}44,52 \pm \\
2.4\end{array}$ & $\begin{array}{c}22,55 \pm \\
1.1\end{array}$ & $\begin{array}{c}28,37 \pm \\
1.8\end{array}$ & $\begin{array}{c}54,97 \pm \\
2.8\end{array}$ & $\begin{array}{c}79,16 \pm \\
4.0\end{array}$ \\
\hline $3 d$ & $\begin{array}{c}10,64 \pm \\
1.2\end{array}$ & $\begin{array}{c}20,27 \pm \\
1.5\end{array}$ & $\begin{array}{c}27,99 \pm \\
1.8\end{array}$ & $\begin{array}{c}46,87 \pm \\
3.1\end{array}$ & $\begin{array}{c}18,62 \pm \\
1.4\end{array}$ & $\begin{array}{c}31,92 \pm \\
1.8\end{array}$ & $\begin{array}{c}52,06 \pm \\
2.2\end{array}$ & $\begin{array}{c}81,06 \pm \\
3.1\end{array}$ & $\begin{array}{c}25,21 \pm \\
1.6\end{array}$ & $\begin{array}{c}53,70 \pm \\
2.3\end{array}$ & $\begin{array}{c}80,11 \pm \\
4.0\end{array}$ & $\begin{array}{c}102,47 \pm \\
5.0\end{array}$ \\
\hline $3 e$ & $\begin{array}{c}10,45 \pm \\
1.1\end{array}$ & $\begin{array}{c}20,01 \pm \\
1.5\end{array}$ & $\begin{array}{c}42,37 \pm \\
2.7\end{array}$ & $\begin{array}{c}51,11 \pm \\
3.8\end{array}$ & $\begin{array}{c}17,16 \pm \\
1.4\end{array}$ & $\begin{array}{c}26,60 \pm \\
1.5\end{array}$ & $\begin{array}{c}35,02 \pm \\
1.7\end{array}$ & $\begin{array}{c}50,28 \pm \\
1.9\end{array}$ & $\begin{array}{c}25,97 \pm \\
1.5\end{array}$ & $\begin{array}{c}48,01 \pm \\
1.9\end{array}$ & $\begin{array}{c}72,70 \pm \\
3.8\end{array}$ & $\begin{array}{c}85,18 \pm \\
4.1\end{array}$ \\
\hline $3 f$ & $\begin{array}{c}18,43 \pm \\
1.5\end{array}$ & $\begin{array}{c}39,01 \pm \\
2.1\end{array}$ & $\begin{array}{c}60,73 \pm \\
3.6\end{array}$ & $\begin{array}{c}66,56 \pm \\
4.1\end{array}$ & $\begin{array}{c}21,72 \pm \\
1.5\end{array}$ & $\begin{array}{c}36,16 \pm \\
1.6\end{array}$ & $\begin{array}{c}49,40 \pm \\
2.0\end{array}$ & $\begin{array}{c}93,79 \pm \\
4.7\end{array}$ & $\begin{array}{c}32,17 \pm \\
1.5\end{array}$ & $\begin{array}{c}34,71 \pm \\
1.8\end{array}$ & $\begin{array}{c}60,67 \pm \\
3.1\end{array}$ & $\begin{array}{c}76,12 \pm \\
3.7\end{array}$ \\
\hline $\mathbf{3 g}$ & $\begin{array}{c}14,12 \pm \\
1.4\end{array}$ & $\begin{array}{c}34,77 \pm \\
2.0\end{array}$ & $\begin{array}{c}60,92 \pm \\
3.4\end{array}$ & $\begin{array}{c}76,50 \pm \\
4.5\end{array}$ & $\begin{array}{c}22,23 \pm \\
1.5\end{array}$ & $\begin{array}{c}72,70 \pm \\
2.3\end{array}$ & $\begin{array}{c}82,77 \pm \\
3.4\end{array}$ & $\begin{array}{c}93,98 \pm \\
5.0\end{array}$ & $\begin{array}{c}20,39 \pm \\
1.4\end{array}$ & $\begin{array}{c}49,27 \pm \\
2.7\end{array}$ & $\begin{array}{c}72,70 \pm \\
3.5\end{array}$ & $\begin{array}{c}100,13 \pm \\
4.3\end{array}$ \\
\hline 3h & $\begin{array}{c}21,15 \pm \\
1.7\end{array}$ & $\begin{array}{c}28,56 \pm \\
1.7\end{array}$ & $\begin{array}{c}50,03 \pm \\
3.3\end{array}$ & $\begin{array}{c}58,71 \pm \\
4.0\end{array}$ & $\begin{array}{c}14,00 \pm \\
1.1\end{array}$ & $\begin{array}{c}22,42 \pm \\
1.3\end{array}$ & $\begin{array}{c}31,86 \pm \\
1.9\end{array}$ & $\begin{array}{c}50,73 \pm \\
2.4\end{array}$ & $\begin{array}{c}24,89 \pm \\
1.4\end{array}$ & $\begin{array}{c}43,57 \pm \\
2.0\end{array}$ & $\begin{array}{c}69,54 \pm \\
3.4\end{array}$ & $\begin{array}{c}85,81 \pm \\
3.9\end{array}$ \\
\hline $3 \mathbf{i}$ & $\begin{array}{c}22,80 \pm \\
1.5\end{array}$ & $\begin{array}{c}48,20 \pm \\
3.7\end{array}$ & $\begin{array}{c}54,53 \pm \\
3.5\end{array}$ & $\begin{array}{c}58,96 \pm \\
4.0\end{array}$ & $\begin{array}{c}18,05 \pm \\
1.1\end{array}$ & $\begin{array}{c}24,70 \pm \\
1.4\end{array}$ & $\begin{array}{c}43,64 \pm \\
1.9\end{array}$ & $\begin{array}{c}45,60 \pm \\
2.3\end{array}$ & $\begin{array}{c}32,68 \pm \\
1.6\end{array}$ & $\begin{array}{c}44,84 \pm \\
1.9\end{array}$ & $\begin{array}{c}72,70 \pm \\
3.4\end{array}$ & $\begin{array}{c}90,63 \pm \\
4.6\end{array}$ \\
\hline
\end{tabular}


Table 7: \% Cytotoxicity of the compounds against Hep3B, MCF7, and C6.

\begin{tabular}{|c|c|c|c|c|c|c|c|c|c|c|c|c|}
\hline \multirow{2}{*}{ \%Cytotoxicity } & \multicolumn{4}{|c|}{ НерЗВ } & \multicolumn{4}{|c|}{ MCF7 } & \multicolumn{4}{|c|}{ C6 } \\
\hline & $25 \mu \mathrm{g} / \mathrm{mL}$ & $50 \mu \mathrm{g} / \mathrm{mL}$ & $75 \mu \mathrm{g} / \mathrm{mL}$ & $100 \mu \mathrm{g} / \mathrm{mL}$ & $25 \mu \mathrm{g} / \mathrm{mL}$ & $50 \mu \mathrm{g} / \mathrm{mL}$ & $75 \mu \mathrm{g} / \mathrm{mL}$ & $100 \mu \mathrm{g} / \mathrm{mL}$ & $25 \mu \mathrm{g} / \mathrm{mL}$ & $50 \mu \mathrm{g} / \mathrm{mL}$ & $75 \mu \mathrm{g} / \mathrm{mL}$ & $100 \mu \mathrm{g} / \mathrm{mL}$ \\
\hline 30 & $10,01 \pm$ & $25,46 \pm$ & $38,38 \pm$ & $51,04 \pm$ & $10,64 \pm$ & $18,49 \pm$ & $29,51 \pm$ & $43,89 \pm$ & $30,27 \pm$ & $66,37 \pm$ & $78,97 \pm$ & $99,94 \pm$ \\
\hline $3 a$ & 0.8 & 2.2 & 2.7 & 3.0 & 0.8 & 1.5 & 1.9 & 3.0 & 1.5 & 3.4 & 4.0 & 5.1 \\
\hline 3b & $\begin{array}{c}14,00 \pm \\
1.0\end{array}$ & $\begin{array}{c}23,81 \pm \\
2.1\end{array}$ & $\begin{array}{c}41,61 \pm \\
2.8\end{array}$ & $\begin{array}{c}55,29 \pm \\
3.0\end{array}$ & $\begin{array}{c}6,84 \pm \\
0.7\end{array}$ & $\begin{array}{c}14,31 \pm \\
1.0\end{array}$ & $\begin{array}{c}32,74 \pm \\
2.1\end{array}$ & $\begin{array}{c}50,66 \pm \\
3.6\end{array}$ & $\begin{array}{c}34,71 \pm \\
1.4\end{array}$ & $\begin{array}{c}64,47 \pm \\
3.5\end{array}$ & $\begin{array}{c}82,08 \pm \\
4.5\end{array}$ & $\begin{array}{c}96,20 \pm \\
5.2\end{array}$ \\
\hline $3 c$ & $\begin{array}{c}11,91 \pm \\
1.1\end{array}$ & $\begin{array}{c}21,22 \pm \\
1.7\end{array}$ & $\begin{array}{c}32,55 \pm \\
2.3\end{array}$ & $\begin{array}{c}49,91 \pm \\
3.1\end{array}$ & $\begin{array}{c}9,37 \pm \\
0.8\end{array}$ & $\begin{array}{c}18,49 \pm \\
1.5\end{array}$ & $\begin{array}{c}26,47 \pm \\
1.9\end{array}$ & $\begin{array}{c}54,21 \pm \\
3.7\end{array}$ & $\begin{array}{c}30,91 \pm \\
1.8\end{array}$ & $\begin{array}{c}67,00 \pm \\
3.9\end{array}$ & $\begin{array}{c}82,96 \pm \\
4.7\end{array}$ & $\begin{array}{c}99,11 \pm \\
5.3\end{array}$ \\
\hline 3d & $\begin{array}{c}19,57 \pm \\
1.5\end{array}$ & $\begin{array}{c}28,88 \pm \\
2.0\end{array}$ & $\begin{array}{c}48,01 \pm \\
2.5\end{array}$ & $\begin{array}{c}60,99 \pm \\
3.8\end{array}$ & $\begin{array}{c}10,01 \pm \\
0.9\end{array}$ & $\begin{array}{c}20,14 \pm \\
1.1\end{array}$ & $\begin{array}{c}27,04 \pm \\
1.8\end{array}$ & $\begin{array}{c}45,35 \pm \\
2.1\end{array}$ & $\begin{array}{c}27,68 \pm \\
1.5\end{array}$ & $\begin{array}{c}63,84 \pm \\
2.9\end{array}$ & $\begin{array}{c}79,42 \pm \\
4.0\end{array}$ & $\begin{array}{c}104,75 \pm \\
5.4\end{array}$ \\
\hline $3 e$ & $\begin{array}{c}18,56 \pm \\
1.4\end{array}$ & $\begin{array}{c}26,35 \pm \\
1.6\end{array}$ & $\begin{array}{c}45,41 \pm \\
2.3\end{array}$ & $\begin{array}{c}51,23 \pm \\
3.4\end{array}$ & $\begin{array}{c}9,37 \pm \\
0.9\end{array}$ & $\begin{array}{c}19,19 \pm \\
1.3\end{array}$ & $\begin{array}{c}30,53 \pm \\
1.9\end{array}$ & $\begin{array}{c}40,28 \pm \\
2.0\end{array}$ & $\begin{array}{c}23,31 \pm \\
1.4\end{array}$ & $\begin{array}{c}62,57 \pm \\
3.1\end{array}$ & $\begin{array}{c}78,28 \pm \\
4.2\end{array}$ & $\begin{array}{c}85,18 \pm \\
4.9\end{array}$ \\
\hline $3 f$ & $\begin{array}{c}14,63 \pm \\
1.2\end{array}$ & $\begin{array}{c}32,68 \pm \\
2.5\end{array}$ & $\begin{array}{c}57,82 \pm \\
3.4\end{array}$ & $\begin{array}{c}70,80 \pm \\
4.1\end{array}$ & $\begin{array}{c}11,91 \pm \\
0.9\end{array}$ & $\begin{array}{c}15,96 \pm \\
1.0\end{array}$ & $\begin{array}{c}29,26 \pm \\
1.5\end{array}$ & $\begin{array}{c}47,31 \pm \\
2.2\end{array}$ & $\begin{array}{c}31,54 \pm \\
1.8\end{array}$ & $\begin{array}{c}55,60 \pm \\
3.1\end{array}$ & $\begin{array}{c}80,56 \pm \\
4.9\end{array}$ & $\begin{array}{c}96,45 \pm \\
5.0\end{array}$ \\
\hline $\mathbf{3 g}$ & $\begin{array}{c}14,31 \pm \\
1.1\end{array}$ & $\begin{array}{c}26,98 \pm \\
2.0\end{array}$ & $\begin{array}{c}35,66 \pm \\
2.7\end{array}$ & $\begin{array}{c}48,51 \pm \\
2.9\end{array}$ & $\begin{array}{c}11,27 \pm \\
0.9\end{array}$ & $\begin{array}{c}19,13 \pm \\
1.4\end{array}$ & $\begin{array}{c}27,68 \pm \\
1.8\end{array}$ & $\begin{array}{c}57,88 \pm \\
3.4\end{array}$ & $\begin{array}{c}25,84 \pm \\
1.1\end{array}$ & $\begin{array}{c}63,84 \pm \\
3.5\end{array}$ & $\begin{array}{c}82,46 \pm \\
4.8\end{array}$ & $\begin{array}{c}97,21 \pm \\
5.4\end{array}$ \\
\hline 3h & $\begin{array}{c}14,25 \pm \\
1.4\end{array}$ & $\begin{array}{c}25,40 \pm \\
2.1\end{array}$ & $\begin{array}{c}39,65 \pm \\
2.9\end{array}$ & $\begin{array}{c}51,68 \pm \\
3.2\end{array}$ & $\begin{array}{c}6,21 \pm \\
0.8\end{array}$ & $\begin{array}{c}16,02 \pm \\
1.2\end{array}$ & $\begin{array}{c}32,11 \pm \\
1.9\end{array}$ & $\begin{array}{c}47,18 \pm \\
2.3\end{array}$ & $\begin{array}{c}29,64 \pm \\
1.4\end{array}$ & $\begin{array}{c}56,87 \pm \\
3.0\end{array}$ & $\begin{array}{c}78,72 \pm \\
4.6\end{array}$ & $\begin{array}{c}93,60 \pm \\
5.0\end{array}$ \\
\hline $3 \mathbf{i}$ & $\begin{array}{c}8,36 \pm \\
0.78\end{array}$ & $\begin{array}{c}25,90 \pm \\
2.0\end{array}$ & $\begin{array}{c}33,82 \pm \\
2.4\end{array}$ & $\begin{array}{c}51,99 \pm \\
3.1\end{array}$ & $\begin{array}{c}8,11 \pm \\
0.7\end{array}$ & $\begin{array}{c}23,75 \pm \\
1.1\end{array}$ & $\begin{array}{c}38,51 \pm \\
2.3\end{array}$ & $\begin{array}{c}50,35 \pm \\
3.4\end{array}$ & $\begin{array}{c}33,44 \pm \\
1.9\end{array}$ & $\begin{array}{c}63,20 \pm \\
3.7\end{array}$ & $\begin{array}{c}81,13 \pm \\
4.2\end{array}$ & $\begin{array}{c}101,01 \pm \\
5.3\end{array}$ \\
\hline
\end{tabular}


Table 8: \% Cytotoxicity of the compounds against Vero and FL.

\begin{tabular}{|c|c|c|c|c|c|c|c|c|}
\hline \multirow{2}{*}{ \%Cytotoxicity } & \multicolumn{4}{|c|}{ Vero } & \multicolumn{4}{|c|}{$F L$} \\
\hline & $25 \mu \mathrm{g} / \mathrm{mL}$ & $50 \mu \mathrm{g} / \mathrm{mL}$ & $75 \mu \mathrm{g} / \mathrm{mL}$ & $100 \mu \mathrm{g} / \mathrm{mL}$ & $25 \mu \mathrm{g} / \mathrm{mL}$ & $50 \mu \mathrm{g} / \mathrm{mL}$ & $75 \mu \mathrm{g} / \mathrm{mL}$ & $100 \mu \mathrm{g} / \mathrm{mL}$ \\
\hline $3 a$ & $\begin{array}{c}19,76 \pm \\
1.5\end{array}$ & $\begin{array}{c}32,93 \pm \\
2.1\end{array}$ & $\begin{array}{c}44,97 \pm \\
2.8\end{array}$ & $\begin{array}{c}73,46 \pm \\
3.9\end{array}$ & $\begin{array}{c}20,08 \pm \\
1.5\end{array}$ & $\begin{array}{c}29,39 \pm \\
1.9\end{array}$ & $\begin{array}{c}57,76 \pm \\
3.5\end{array}$ & $\begin{array}{c}72,96 \pm \\
4.0\end{array}$ \\
\hline 3b & $\begin{array}{c}16,85 \pm \\
1.5\end{array}$ & $\begin{array}{c}29,32 \pm \\
1.9\end{array}$ & $\begin{array}{c}56,87 \pm \\
3.2\end{array}$ & $\begin{array}{c}81,63 \pm \\
4.2\end{array}$ & $\begin{array}{c}15,64 \pm \\
1.1\end{array}$ & $\begin{array}{c}29,83 \pm \\
1.7\end{array}$ & $\begin{array}{c}48,77 \pm \\
3.0\end{array}$ & $\begin{array}{c}70,87 \pm \\
4.1\end{array}$ \\
\hline $3 c$ & $\begin{array}{c}17,23 \pm \\
1.3\end{array}$ & $\begin{array}{c}36,67 \pm \\
2.2\end{array}$ & $\begin{array}{c}51,61 \pm \\
2.9\end{array}$ & $\begin{array}{c}60,99 \pm \\
3.7\end{array}$ & $\begin{array}{c}14,88 \pm \\
1.2\end{array}$ & $\begin{array}{c}32,74 \pm \\
2.1\end{array}$ & $\begin{array}{c}44,59 \pm \\
2.9\end{array}$ & $\begin{array}{c}68,14 \pm \\
3.7\end{array}$ \\
\hline $3 d$ & $\begin{array}{c}17,99 \pm \\
1.2\end{array}$ & $\begin{array}{c}33,38 \pm \\
1.9\end{array}$ & $\begin{array}{c}52,56 \pm \\
3.1\end{array}$ & $\begin{array}{c}74,48 \pm \\
3.9\end{array}$ & $\begin{array}{c}25,40 \pm \\
1.6\end{array}$ & $\begin{array}{c}65,10 \pm \\
2.9\end{array}$ & $\begin{array}{c}70,93 \pm \\
4.1\end{array}$ & $\begin{array}{c}77,33 \pm \\
4.4\end{array}$ \\
\hline $3 e$ & $\begin{array}{c}14,95 \pm \\
1.0\end{array}$ & $\begin{array}{c}30,91 \pm \\
1.8\end{array}$ & $\begin{array}{c}63,77 \pm \\
3.4\end{array}$ & $\begin{array}{c}79,16 \pm \\
4.0\end{array}$ & $\begin{array}{c}18,94 \pm \\
1.4\end{array}$ & $\begin{array}{c}33,38 \pm \\
1.7\end{array}$ & $\begin{array}{c}46,55 \pm \\
2.4\end{array}$ & $\begin{array}{c}66,75 \pm \\
2.9\end{array}$ \\
\hline $3 f$ & $\begin{array}{c}23,69 \pm \\
1.5\end{array}$ & $\begin{array}{c}34,33 \pm \\
1.8\end{array}$ & $\begin{array}{c}54,65 \pm \\
2.7\end{array}$ & $\begin{array}{c}87,71 \pm \\
5.0\end{array}$ & $\begin{array}{c}29,32 \pm \\
1.4\end{array}$ & $\begin{array}{c}54,34 \pm \\
2.0\end{array}$ & $\begin{array}{c}82,08 \pm \\
4.3\end{array}$ & $\begin{array}{c}93,35 \pm \\
5.1\end{array}$ \\
\hline $3 \mathbf{g}$ & $\begin{array}{c}18,11 \pm \\
1.4\end{array}$ & $\begin{array}{c}30,40 \pm \\
2.0\end{array}$ & $\begin{array}{c}59,66 \pm \\
3.5\end{array}$ & $\begin{array}{c}83,09 \pm \\
4.5\end{array}$ & $\begin{array}{c}16,21 \pm \\
1.2\end{array}$ & $\begin{array}{c}37,75 \pm \\
2.4\end{array}$ & $\begin{array}{c}46,61 \pm \\
2.8\end{array}$ & $\begin{array}{c}70,74 \pm \\
4.0\end{array}$ \\
\hline 3h & $\begin{array}{c}19,25 \pm \\
1.4\end{array}$ & $\begin{array}{c}32,74 \pm \\
1.7\end{array}$ & $\begin{array}{c}64,28 \pm \\
3.0\end{array}$ & $\begin{array}{c}80,30 \pm \\
4.4\end{array}$ & $\begin{array}{c}19,19 \pm \\
1.5\end{array}$ & $\begin{array}{c}46,42 \pm \\
1.8\end{array}$ & $\begin{array}{c}59,91 \pm \\
3.6\end{array}$ & $\begin{array}{c}72,32 \pm \\
4.0\end{array}$ \\
\hline $3 \mathbf{i}$ & $\begin{array}{c}11,91 \pm \\
0.9\end{array}$ & $\begin{array}{c}24,13 \pm \\
1.5 \\
\end{array}$ & $\begin{array}{c}43,19 \pm \\
2.9\end{array}$ & $\begin{array}{c}54,02 \pm \\
3.5\end{array}$ & $\begin{array}{c}28,37 \pm \\
1.6\end{array}$ & $\begin{array}{c}43,57 \pm \\
1.9\end{array}$ & $\begin{array}{c}63,84 \pm \\
3.8\end{array}$ & $\begin{array}{c}73,46 \pm \\
4.2\end{array}$ \\
\hline
\end{tabular}

Table 9: \% Cytotoxicity of positive controls at IC50 concentrations.

\begin{tabular}{ccccccccc}
\hline & HeLa & HT29 & A549 & MCF7 & C6 & ep3B & FL & Vero \\
\hline \multirow{2}{*}{ Cisplatin } & $9.85 \pm$ & $11.23 \pm$ & $8.63 \pm$ & $10.71 \pm$ & $9.04 \pm$ & $8.46 \pm$ & $8.33 \pm$ & $9.41 \pm$ \\
& 0.8 & 0.9 & 0.8 & 0.9 & 0.8 & 0.8 & 0.7 & 0.9 \\
\multirow{2}{*}{ 5FU } & $8.83 \pm$ & $7.91 \pm$ & $9.19 \pm$ & $7.69 \pm$ & $10.01 \pm$ & $9.67 \pm$ & $8.44 \pm$ & $8.81 \pm$ \\
& 0.7 & 0.7 & 0.8 & 0.7 & 0.9 & 0.8 & 0.8 & 0.9
\end{tabular}

Values are given as the mean \pm SD of three experiments and $r^{2}=0.95$ to 0.98 . Significant at $P<0.05$ 

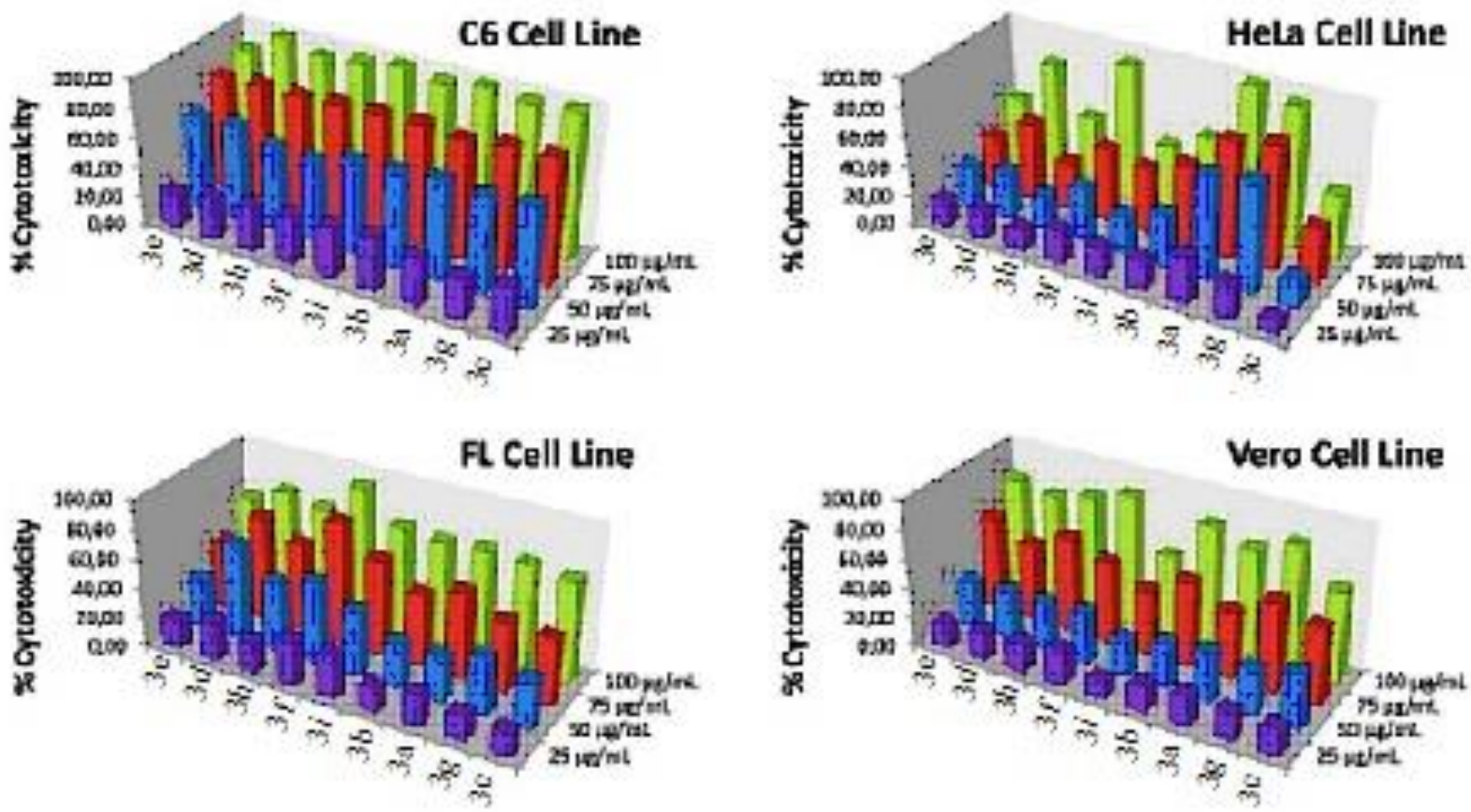

Figure 5. The cytotoxic activity of the compounds on C6, HeLa, FL, and Vero cells. Exponentially growing cells were incubated with various concentrations of the Schiff bases and cytotoxicity was measured by LDH Cytotoxicity Assay.

\section{The Effect of the 3d on the Morphology of the Cells}

The morphology alters of treated and untreated (control) cells were monitored by using the inverted phase-contrast microscopy techniques. As shown in Figures 6 and 7, visible morphology alters such as cytoplasmic blebs, anomalous globular structure and reduction in cell quality and cell count in the flask monolayer were recorded.

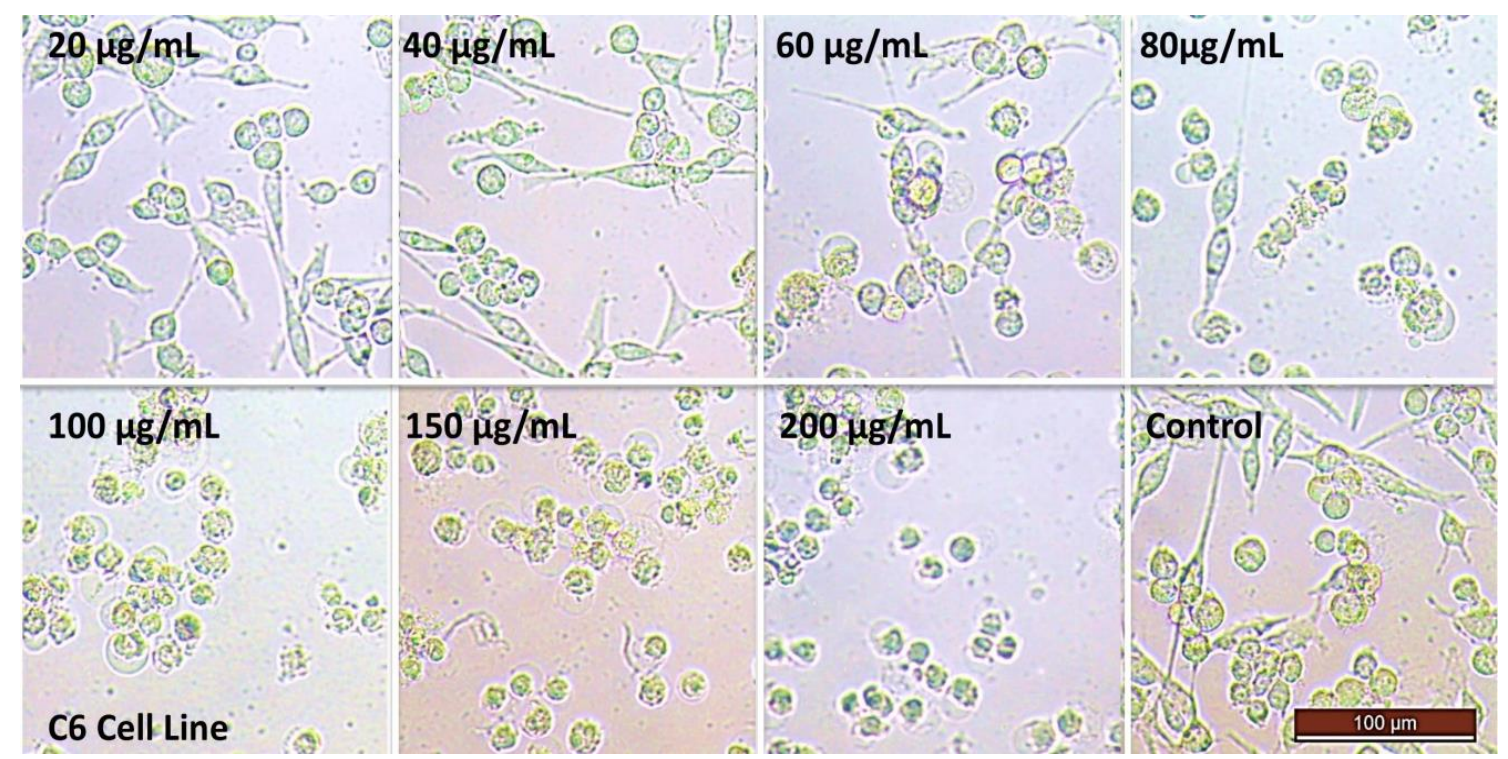

Figure 6: The effect of 3d on the morphology of C6 cell line. Exponentially growing cells were incubated by adding various concentrations of $\mathbf{3 d}$ at $37^{\circ} \mathrm{C}$ overnight. Control cells were treated with only DMSO. 


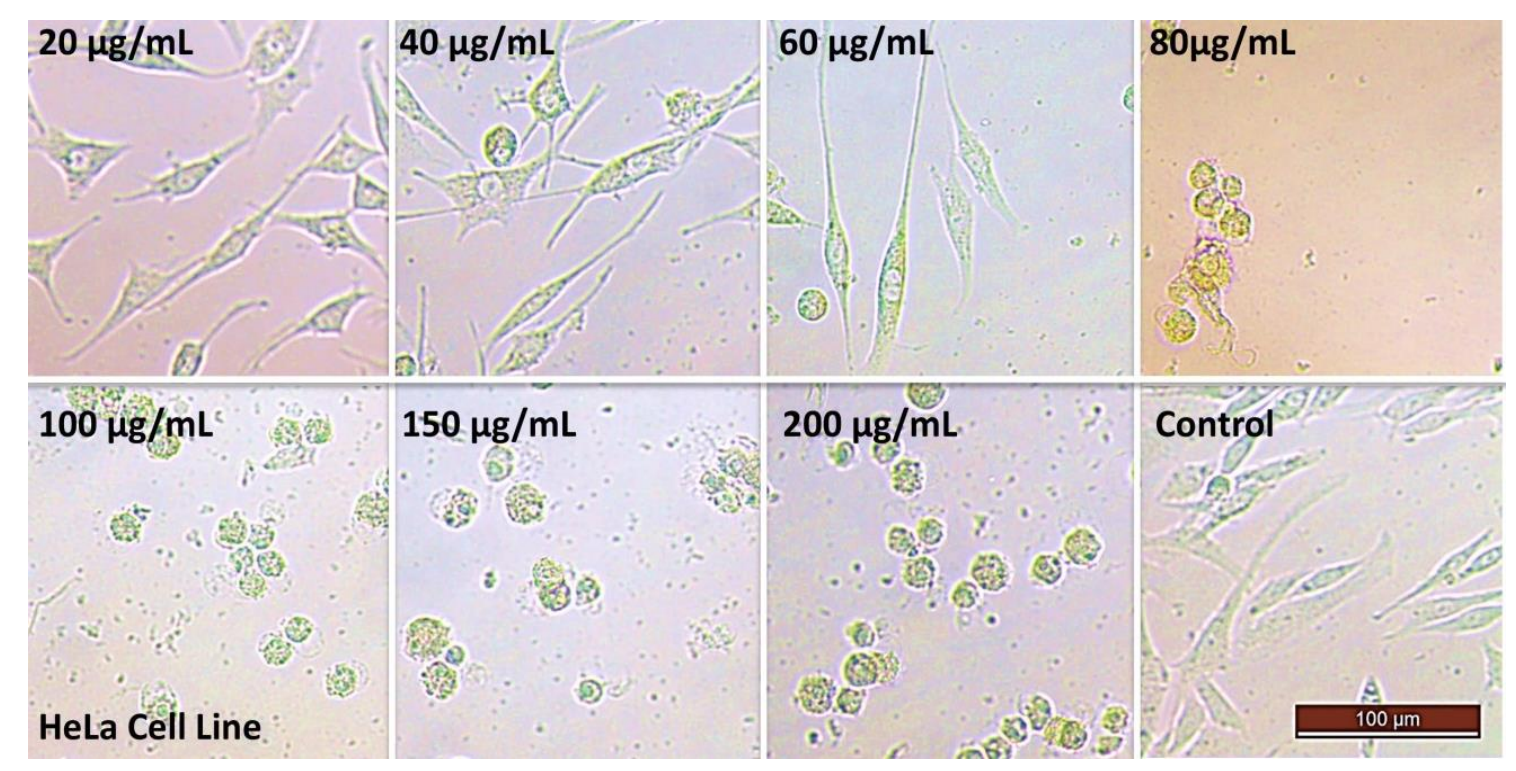

Figure 7: The effect of 3d on the morphology of HeLa cell line. Exponentially growing cells were incubated by adding various concentrations of $\mathbf{3 d}$ at $37^{\circ} \mathrm{C}$ overnight. Control cells were treated with only DMSO.

\section{CONCLUSIONS}

In brief, a new series of amino acid methyl ester Schiff bases (3a-i) was prepared and characterized by spectroscopic methods (FT-IR, UV-Vis, ${ }^{1} \mathrm{H}$ - and ${ }^{13} \mathrm{C}-\mathrm{NMR}$ ). Schiff bases were synthesized by condensation reactions of salicylaldehyde derivatives and amino acid methyl esters in alkaline chloroform media. All analysis results were in accordance with suggested Schiff base structures. All Schiff bases were validated against A549, HeLa, HT29, Hep3B, MCF7 and C6 cell lines by the MTT assay. According to the results, all of the imine compounds exhibited selectivity for aforementioned carcinoma cell lines. Especially, compound 3d was the most active compound against all tested cell lines with good TGI and IC50 values of $5.81-52.36 \mu \mathrm{g} / \mathrm{mL}$ and $5.72-46.35 \mu \mathrm{g} / \mathrm{mL}$, respectively. GI50, TGI and LC50 values of the Schiff bases $\mathbf{3 a - i}$ emphasized that they satisfied the NCI-60 criteria to pass into further pharmacological investigations. Although full mechanism underlying the cytotoxic activity could not be explained, it is known that some organic substituents like phenyl, halogens, hydroxy and methoxy enhance cytotoxic activity. It can be concluded that the existence of two phenyl rings and bromo substituent and the position of bromo group highlight compound $\mathbf{3 d}$ as a strong anticancer agent.

\section{REFERENCES}

1. Tidwell TT. Hugo (Ugo) Schiff, Schiff Bases and a Century of $\beta$-Lactam Synthesis. Angewandte Chemie International Edition. 2008; 47(6): 1016-20.

2. Malladi S, Isloor AM, Isloor S, Akhila DS, Fun H-K, Synthesis, characterization and antibacterial activity of some new pyrazole based Schiff bases. Arabian Journal of Chemistry. 2013; 6(3): 335-40. 
3. Wang J, Lian Z, Wang H, Jin X, Liu Y. Synthesis and antimicrobial activity of Schiff base of chitosan and acylated chitosan. Journal of Applied Polymer Science. 2012; 123(6): 3242-7.

4. Goszczyńska A, Kwiecień H, Fijałkowski K. Synthesis and antibacterial activity of Schiff bases and amines derived from alkyl 2-(2-formyl-4-nitrophenoxy)alkanoates. Medicinal Chemistry Research. 2015; 24(9): 3561-77.

5. Sikarwar P, Tomar S, Singh AP. Synthesis, Spectral Characterization and Antimicrobial Activity of Schiff Bases and Their Mixed Ligand Metal Complexes of $\mathrm{Co}(\mathrm{II}), \mathrm{Ni}(\mathrm{II}), \mathrm{Cu}(\mathrm{II})$ and $\mathrm{Zn}$ (II). American Journal of Chemistry. 2016; 6(5): 119-25.

6. Chigurupati S. Designing New Vanillin Schiff Bases and their Antibacterial Studies. Journal of Medical and Bioengineering. 2015; 4(5): 363-6.

7. Yang Q, Sun X, Liu Y, Chen B, Shen S. Synthesis and Antifungal Activity of Schiff Bases of 5Ethoxycarbonylmethylsulfanyl-1,2,4-triazole. Chinese Journal of Applied Chemistry. 2014; 31(07): 78892.

8. Rehman W, Baloch MK, Muhammad B, Badshah A, Khan KM. Characteristic spectral studies and in vitro antifungal activity of some Schiff bases and their organotin (IV) complexes. Chinese Science Bulletin. $2004 ; 49(2): 119-22$.

9. Guo Z, Xing R, Liu S, Zhong Z, Ji X, Wang L, Pengcheng L. Antifungal properties of Schiff bases of chitosan, $N$-substituted chitosan and quaternized chitosan. Carbohydrate Research. 2007; 342(10): 1329-32.

10. Karthikeyan MS, Prasad DJ, Poojary B, Bhat KS, Holla BS, Kumari NS. Synthesis and biological activity of Schiff and Mannich bases bearing 2,4-dichloro-5-fluorophenyl moiety. Bioorganic \& Medicinal Chemistry. 2006; 14(22): 7482-9.

11. Panneerselvam P, Nair RR, Vijayalakshmi G, Subramanian EH, Sridhar SK. Synthesis of Schiff bases of 4-(4-aminophenyl)-morpholine as potential antimicrobial agents. European Journal of Medicinal Chemistry. 2005; 40(2): 225-9.

12. Abd-Elzaher MM, Labib AA, Mousa HA, Moustafa SA, Ali MM, El-Rashedy AA. Synthesis, anticancer activity and molecular docking study of Schiff base complexes containing thiazole moiety. Beni-Suef University Journal of Basic and Applied Sciences. 2016; 5(1): 85-96.

13. Poonia K, Siddiqui S, Arshad M, Kumar D. In vitro anticancer activities of Schiff base and its lanthanum complex. Spectrochimica Acta Part A: Molecular and Biomolecular Spectroscopy. 2016; 155: 146-54.

14. Shukla S, Srivastava RS, Shrivastava SK, Sodhi A, Kumar P. Synthesis, characterization, in vitro anticancer activity, and docking of Schiff bases of 4-amino-1,2-naphthoquinone. Medicinal Chemistry Research. 2013; 22(4): 1604-17.

15. Emam SM, El Sayed IET, Ayad MI, Hathout HMR. Synthesis, characterization and anticancer activity of new Schiff bases bearing neocryptolepine. Journal of Molecular Structure. 2017; 1146: 600-19.

16. Kuzmin VE, Artemenko AG, Lozytska RN, Fedtchouk AS, Lozitsky VP, Muratov EN, Mescheriakov AK. Investigation of anticancer activity of macrocyclic Schiff bases by means of 4D-QSAR based on simplex representation of molecular structure. SAR and QSAR in Environmental Research. 2005; 16(3): 219-30.

17. Luo $H$, Sui $Y$, Lin $W-H$, Wu H-Q. Study on the antiproliferative activity of four Schiff bases derived from natural biomass dehydroabiethylamine. Indian Journal of Chemistry. 2016; 55B(2): $248-51$.

18. Harpstrite SE, Collins SD, Oksman A, Goldberg DE, Sharma V. Synthesis, characterization, and antimalarial activity of novel schiff-base-phenol and naphthalene-amine ligands. Medicinal Chemistry. 2008; 4(4): 392-5.

19. Sharma R, Goswami A, Rudrapal M, Sharma D, Kumar Sharma H, Chetia D. In vitro evaluation of the antimalarial activity of a designed novel quinuclidine derivative. Current Science. 2016; 111(12): 202830. 
20. Sharma M, Chauhan K, Srivastava RK, Singh SV, Srivastava K, Saxena JK, Puri SK, Chauhan PMS. Design and Synthesis of a New Class of 4-Aminoquinolinyl- and 9-Anilinoacridinyl Schiff Base Hydrazones as Potent Antimalarial Agents. Chemical Biology \& Drug Design. 2014; 84(2): 175-81.

21. Bringmann G, Dreyer M, Faber JH, Dalsgaard PW, Staerk D, Jaroszewski JW, Ndangalasi H, Mbago F, Brun R, Christensen SB. Ancistrotanzanine $C$ and related 5,1'- and 7,3'-coupled naphthylisoquinoline alkaloids from Ancistrocladus tanzaniensis. Journal of Natural Products. 2004; 67(5): 743-8.

22. Rathelot $P$, Vanelle $P$, Gasquet $M$, Delmas F, Crozet MP, Timon-David P, Maldonado J. Synthesis of novel functionalized 5-nitroisoquinolines and evaluation of in vitro antimalarial activity. European Journal of Medicinal Chemistry. 1995; 30(6): 503-8.

23. Tadele KT. Antioxidant Activity of Schiff Bases and Their Metal Complexes: A Recent Review. Journal of Pharmaceutical and Medicinal Research. 2017; 3(1): 73-7.

24. Anouar EH, Raweh S, Bayach I, Taha M, Baharudin MS, Di Meo F, Hasan MH, Adam A, Ismail NH, Weber JF, Trouillas P. Antioxidant properties of phenolic Schiff bases: structure-activity relationship and mechanism of action. Journal of Computer-Aided Molecular Design. 2013; 27(11): 951-64.

25. Guo Z, Xing R, Liu S, Yu H, Wang P, Li C, Li P. The synthesis and antioxidant activity of the Schiff bases of chitosan and carboxymethyl chitosan. Bioorganic \& Medicinal Chemistry Letters. 2005; 15(20): 4600-3.

26. Brodowska K, Sykuła A, Garribba E, Łodyga-Chruścińska E, Sójka M. Naringenin Schiff base: antioxidant activity, acid-base profile, and interactions with DNA. Transition Metal Chemistry. 2016; 41(2): 179-89.

27. Ozdemir M, Sonmez M. Antioxidant Activity, Synthesis and Characterization of Schiff Base Ligand 'asasp' and Metal Complexes. Asian Journal of Chemistry. 2014; 26(20): 7009-15.

28. Turan N, Bursal E, Çolak N, Buldurun K. Investigation of Synthesis, Structural Characterization, Antioxidant Activities and Thermal Properties of $\mathrm{Zn}(\mathrm{II}), \mathrm{Fe}(\mathrm{II})$ and $\mathrm{Mn}$ (II) Complexes with ThiopheneCarboxylate Ligand. Journal of Chemistry and Biochemistry. 2015; 3(2): 13-29.

29. Liu G, Cogan D, Ellman JA. Catalytic asymmetric synthesis of tert-butanesulfinamide. Application to the asymmetric synthesis of amines. Journal of the American Chemical Society. 1997; 119(41): 9913-4.

30. Cimarelli C, Palmieri G. Asymmetric reduction of enantiopure imines with zinc borohydride: stereoselective synthesis of chiral amines. Tetrahedron: Asymmetry. 2000; 11(12): 2555-63.

31. Yendapally R, Hurdle JG, Carson EI, Lee RB, Lee RE. N-Substituted 3-Acetyltetramic Acid Derivatives as Antibacterial Agents. Journal of Medicinal Chemistry. 2008; 51(5): 1487-91.

32. Barreau M, Commercon A, Mignani S, Mouysset D, Perfetti $P$, Stella L. Stereoselective synthesis of racemic a-amino-acid derivatives with a $\beta$-lactam skeleton: Application of the Staudinger reaction to chiral imines of methyl glyoxylate. Tetrahedron. 1998; 54(38): 11501-16.

33. Hasegawa M, Taniyama D, Tomioka K. Facile Asymmetric Synthesis of a-Amino Acids Employing Chiral Ligand-Mediated Asymmetric Addition Reactions of Phenyllithium with Imines. Tetrahedron. 2000; 56(52): 10153-8.

34. Blaney P, Grigg R, Rankovicb Z, Thornton-Petta M, Xu J. Fused and bridged bi- and tri-cyclic lactams via sequential metallo-azomethine ylide cycloaddition-lactamisation. Tetrahedron. 2002; 58(9): 1719-37.

35. Grigg R, Sridharan V, Suganthan S, Bridge AW. Sequential and Cascade 1,3-Dipolar CycloadditionPalladium Catalysed Carbonylation-Cyclisation Reactions. Diastereospecific and Homochiral Processes. Tetrahedron. 1995; 51(1): 295-306.

36. Davis FA, Sheppard AC. Applications of oxaziridines in organic synthesis. Tetrahedron. 1989; 45(18): 5703-42.

37. Petrov VA, Resnati G. Polyfluorinated Oxaziridines: Synthesis and Reactivity. Chemical Reviews. 1996; 96(5): 1809-23. 
38. Al-Garawi ZSM, Tomi IHR, Al-Daraji AHR. Synthesis and Characterization of New Amino Acid-Schiff Bases and Studies their Effects on the Activity of ACP, PAP and NPA Enzymes (In Vitro). E-Journal of Chemistry. 2012; 9(2): 962-9.

39. Zhang L, Jiang $H$, Cao $X$, Zhao H, Wang F, Cui Y, Jiang B. Chiral gossypol derivatives: Evaluation of their anticancer activity and molecular modeling. European Journal of Medicinal Chemistry. 2009; 44(10): 3961-72.

40. Xia L, Xia Y-F, Huang L-R, Xiao X, Lou H-Y, Liu T-J, Pan W-D, Luo H. Benzaldehyde Schiff bases regulation to the metabolism, hemolysis, and virulence genes expression in vitro and their structure microbicidal activity relationship. European Journal of Medicinal Chemistry. 2015; 97: 83-93.

41. Kumar S, Priya Matharasi D, Gopi S, Sivakumar S, Narasimhan S. Synthesis of cytotoxic and antioxidant Schiff's base analogs of aloin. Journal of Asian Natural Products Research. 2010; 12(5): 36070.

42. Joksovic MD, Bogdanovic G, Kojic V, Szecsenyi KM, Leovac VM, Jakimov D, Trifunovic S, Markovic V, Joksovica L. Synthesis, Cytotoxic Activity, and Thermal Studies of Novel N-[(1,3-Diphenylpyrazol-4yl)methyl] a-Amino Acids. Journal of Heterocyclic Chemistry. 2010; 47(4): 850-6.

43. Li L-J, Fu B, Qiao Y, Wang C, Huang Y-Y, Liu C-C, Tian C, Du J-L. Synthesis, characterization and cytotoxicity studies of platinum(II) complexes with reduced amino acid ester Schiff-bases as ligands. Inorganica Chimica Acta. 2014; 419: 135-40.

44. Zhoua Y, Zhao M, Wub Y, Li C, Wub J, Zheng M, Peng L, Peng S. A class of novel Schiff's bases: Synthesis, therapeutic action for chronic pain, anti-inflammation and 3D QSAR analysis. Bioorganic \& Medicinal Chemistry. 2010; 18(6): 2165-72.

45. Abdel-Rahman LH, Abu-Dief, AM, Ismael M, Mohamed MAA, Hashem NA. Synthesis, structure elucidation, biological screening, molecular modeling and DNA binding of some $\mathrm{Cu}(\mathrm{II})$ chelates incorporating imines derived from amino acids. Journal of Molecular Structure. 2016; 1103(5): 232-44. 